\title{
THE APPLICATION OF ISLAMIC LAW IN INDONESIA: The Case Study of Aceh ${ }^{1}$ \\ Kamaruzzaman Bustamam-Ahmad La Trobe University - Australia
}

\begin{abstract}
This article provides an historical account of the implementation of Islamic law in Aceh and how the issue of Islamic law has been debated. The study will give more emphasis on the dynamics of the implementation of Islamic law, its historical development, typologies of Islamic law, leaders' opinions regarding this issue, and the governments' responses. This study argues that Islamic law in Aceh has been misinterpreted merely as $h \mathfrak{h} d u \bowtie$ law. In addition, it argues that the provincial government tends to put heavy emphasis on symbolic religious issues (such as the Islamic dress code and the usage of Arabic signs and letterheads), rather than the substance of Islamic law such as justice and prosperity for all. Finally, the study has made evident that implementing Islamic law is never a good method of attempting to resolve conflict. There is no need to establish Islamic law formally through the political process because, when politics enters in religious arena, it carries with it many interests.
\end{abstract}

Keywords: Aceh, Shari Q Qanun, Adat, Hndulج.

\section{Introduction}

J.N.D. Anderson in his remarkable book, Islamic Law in the Modern World, maintains that the legal systems of the Muslim world today can be broadly divided into three groups: (1) those that still consider the shari as the fundamental law and still practice it to a certain extent in their countries; (2) those that have abandoned the shari and become

\footnotetext{
1 This article is part of my project which is funded by AMAN (Asian Muslim Action Network), Bangkok, Thailand in 2004. I am greatly indebted to Abdus Sabur, Imtiyaz Yusuf, Alan Feinstain, Bornie, Patrick Jory, for their valuable comments on the draft.
} 
secular, and; (3) those that have reached some compromise between theses two positions. ${ }^{2}$

In this context, it can be said that to a large degree the Southeast Asian states that have a Muslim majority-Malaysia, Indonesia, and Brunei Darussalam - also apply Islamic law. Historically, shari was implemented in conjunction with local customary law (adat) and/or colonial law. ${ }^{3}$ In addition, customary law included certain aspects of Buddhist and Hindu traditions, which had arrived several centuries earlier. In the thirteenth century, Islam came to Southeast Asia and Islamized the traditions. ${ }^{4}$ Islamic law developed within the region and was practiced in certain socio-cultural-political situations. It served as an important factor in unifying Islamic kingdoms in Southeast Asia. ${ }^{5}$

In the fifteenth century where Aceh was under colonialism, Islamic law began to be replaced by colonial legal systems in the areas of commerce and trade as well as in certain political institutions, such as judiciaries and central or local administrations, to the extent that colonialism demanded. ${ }^{6}$

After independence, numerous Islamic groups pressured their governments to cease using colonial law and replace it with Islamic law. In Indonesia, this movement has persisted since Kartosuwiryo and his allies advocated Islamic statehood for Indonesia and the use of Islamic law throughout the country. ${ }^{7}$ In Malaysia, the 1957 constitution placed Islam firmly within the state structure while at the same time

2 J.N.D. Anderson, Islamic Law in the Modern World (New York: New York University Press, 1959), p. 83.

3 Nobuyuki Yasuda, "Law and Development in ASEAN Countries," ASEAN Economic Bulletin 10(2) (1993): 144-154. See also Christine Dobbin, "Islamic Revivalism in Minangkabau at the Turn of the Nineteenth Century," Modern Asian Studies, Vol.8, No.3 (1974), 319-345; Taufik Abdullah, "Adat and Islam: An Examination of Conflict in Minangkabau," Indonesia, No.2 (1966), 1-24; Cf. Taufik Abdullah, "Some Notes on the Kaba Tjindua Mato: An Example of Minangkabau Traditional Literature," Indonesia, No.9 (1970), pp. 1-22.

${ }^{4}$ On the coming of Islam to Malay, see G.W.J. Drewes, "New Light on the Coming of Islam to Indonesia," in Ahmad Ibrahim et al. (eds.), Readings on Islam in Southeast Asia (Singapore: Institute of Southeast Asian Studies, 1985), pp. 7-19.

${ }^{5}$ M.B. Hooker, Islamic Law in Southeast Asia (Singapore: Oxford Univesity Press, 1984).

${ }^{6}$ Nobuyuki Yasuda, "Law and Development," 148. See also, Abdullah Alwi Haji Hassan, The Administration of Islamic Law in Kelantan (Kuala Lumpur: Dewan Bahasa dan Pustaka, 1996), pp. xli-lii.

${ }^{7}$ Holk H. Dengel, Darul Islam dan Kartosumirjo (Jakarta: Sihar Harapan, 1995). 
guaranteeing religious freedom for non-Muslims. ${ }^{8}$ Subsequently in parts of Malaysia, Islamic law has been used to replace the earlier law of the British Empire. In Indonesia, while the Dutch colonial law is still used, some aspects of Islamic law are being practiced in several provinces, such as Aceh and other parts of Sumatra as well as parts of Java.

For several decades leaders in Aceh has urged their national governments (Indonesia and Malaysia, respectively) to allow them to implement Islam in their own province. In Aceh, Daud Beureueh, the most prominent Acehnese Islamic leader, asked Indonesian President Sukarno to have Aceh implement Islamic law and be granted special autonomy. ${ }^{9}$ Daud Beureueh used a radical strategy and revolted against the Sukarno regime. This movement has been continued by the Aceh Liberation Movement (GAM), which was formerly led by Tgk. Hasan di Tiro, a descendant of Tgk. Chik Di Tiro, an Acehnese hero of the Dutch-Aceh War. Aceh has finally achieved new status. In 1999, the Indonesian government granted Aceh the status of "special autonomy" (otonomi khusus) and allowed it to implement Islamic law. By issuing Regulation UU 44/1999, the Indonesian government formalized the opportunity for Aceh to apply Islamic law. GAM, however, rejected this status and asked that Aceh secede from Indonesia. ${ }^{10}$ Some studies have maintained that Indonesia's granting of special autonomy to Aceh province is not the best way to solve the problem. ${ }^{11}$ In any event, even with the implementation of special autonomy, conflicts remain in which the central government continues to attempt to resolve through

\footnotetext{
${ }^{8}$ Fred R. Von Der Mehden, "Malaysia: Islam and Multiethnic Polities," in John L. Esposito (ed.), Islam in Asia: Religion, Politics, and Society (New York: Oxford University Press, 1987), p. 187; G.W. Choudhury, Islam and the Modern Muslim World (Kuala Lumpur: WHS Publications, 1993), pp. 163-164. See also Joseph M. Fernando, "The Position of Islam in the Constitution of Malaysia," Journal of Southeast Asian Studies, Vol.37, No.2 (2006), pp. 249-266; Herbert Feith and Lance Castles (eds.), Pemikiran Politik Indonesia 1945-1965, trans. by Min Yubahar (Jakarta: LP3ES, n.d.), p. 208.

${ }^{9}$ For Daud's statement, see Herbert Feith and Lance Castles (eds.), Pemikiran Politike Indonesia 1945-1965, pp. 208-211.

10 ICG Asia Report No 18, “Aceh: Can Autonomy Stem the Conflict?” June 27, 2001.

11 For a chronology of its legal status, see Kaoy Syah and Lukman Hakiem (eds.), Keistimewaan Aceh dalam Lintasan Sejarah: Proses Pembentukan UU No.44/1999 (Jakarta: Pengurus Besar Al-Jami'iyatul Washliyyah, n.d.).
} 
martial law (darurat militer). ${ }^{12}$ At the same time, the Islamic courts in Aceh have produced several Islamic laws (qanuns) to implement the law. ${ }^{13}$

This article focuses on the application of Islamic law in Aceh, Indonesia. The most interesting issue concerns the dynamics of how Islamic law has been implemented in the place thus far and how this issue has become the source of conflict in the province. In Aceh, we will see how the conflict between GAM and the Indonesian military (TNI) has resulted in serious impacts on the implementation of Islamic law. The aspects that this study will analyze are: the historical development of the implementation of Islamic law, typologies of Islamic law, leaders' opinions regarding this issue, and the governments' responses. In addition, it will observe the various historical, political, economic, and social factors - at both national and international levels - that have significantly contributed to the movement to implement Islamic law in Aceh. In these ways this research will provide empirically rich analyses of how Islamic law has raised issues in particular places at specific times.

This study will also explore the socio-political backdrop to the implementation of Islamic law in Aceh. It is important to understand the sociological implications of the law and the political causes of its emergence in relation to certain political and social contexts. Since the implementation of Islamic law is not a single narrative, it cannot be separated from the history of Aceh as a whole. In addition, it will pose the question of why challenges to the existence of Islamic law are coming not only from the non-Islamic community, but also from the Islamic community itself. Finally, this study will provide a sociological understanding of religious law as a source of conflict and identity.

\section{Re-Orientation on Islamic Law}

This section aims to shed light on some definitions of Islamic law and issues relevant to this subject. There are many books, articles,

12 For a brief inquiry of this story, see Kamaruzzaman Bustamam-Ahmad, Satu Dasawarwa the Clash of Civilizations (Yogyakarta: Ar-Ruzz, 2003), pp. 195-203; Cf. his "Menakar Harga Kemarahan Orang Aceh: Etnograpi Kekerasan di Indonesia," in Hasanuddin Yusuf Adan, Tamaddun dan Sejarab: Etnografi Kekerasan di Aceh (Yogyakarta: Ar-Ruzz, 2003), pp. 9-38.

13 Muhammad Alfian Dja'far, "Independensi Mahkamah Syariah Nanggroew Aceh Darussalam,” bachelor's thesis, State Institute of Islamic Studies, Yogyakarta, 2003. 
theses or dissertations, as well as research reports explaining Islamic law through various languages and perspectives. ${ }^{14}$ The main concern in this section is the actual Islamic law, since scholars have referred to

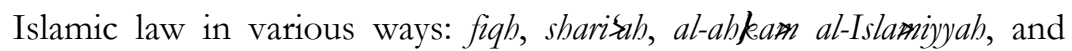
Islamic jurisprudence. The debate on this issue has serious implications for realizing Islamic law as a tool in Muslims' daily life. As A. Qodri Azizy states, "many people are confused in understanding Islamic law, because they think that Islamic law is identical with the shari or even the waby\}(revelation) of God." 15

To explore this point, let us begin with the broad definition given by Joseph Schacht, ${ }^{16}$ who describes Islamic law as

The epitome of Islamic thought, the most typical manifestation of the Islamic way of life, the core and kernel of Islam itself. The very term figh, 'knowledge', shows that early Islam regarded knowledge of the sacred Law as the knowledge par excellence. ${ }^{17}$

Zafar Ishaq Ansari begins his foreword with Schacht's opinion, but goes further by saying that "there can be no denying that among

14 See generally, Joseph Schacht, The Origins of Mubammadan Jurisprudence; Wael B. Hallaq, A History of Islamic Legal Theories: An Introduction to Sunni Usul Fiqh; Robert Gleave, Inevitable Doubt: Two Theories of Shi i Jurisprudence; R. Gleave and E. Kermeli (eds.), Islamic Law: Theory and Practice: Bernard G. Weiss (ed.), Studies in Islamic Legal Theory; Baber Johansen, Contingency in A Sacred Law: Legal and Ethical Norms in the Muslim Fiqh; Mohd. Khalid Mas'ud, et al. (eds.), Islamic Legal Interpretation; David S. Powers, Studies in Qur'an and Hadith: The Formation of the Islamic Law of Inheritance; Ann Elizabeth Mayer (ed.), Property, Social Structure and Law in the Modern Middle East, idem, Islam and Human Rights: Tradition and Politics; Abdullahi Ahmed An-Naim, Toward an Islamic Reformation: Civil Liberties, Human Rights, and International Law; Mahmud Saedon Awang Othman, "Islamic Law and Its Codification", pp. 51-82; Robert Roberts, The Social Laws of the Qur'an; Tahir Mahmood (ed.), Human Rights in Islamic Law; David E. Guinn et.al. (eds.), Religion and Law in the Global Village.

15 A. Qodri Azizy, "Juristic Differences (Ikbtilaf) in Islamic Law: Its Meaning, Early Discussions, and Reasons (A Lesson for Contemporary Characteristics)", p. 264.

16 On Joseph Schacht, see George F. Hourani, "Joseph Schacht, 1902-69”, Journal of the American Oriental Society, Vol. 90, No. 2, 1970: pp. 167-167; Aharon Layish, "Notes on Joseph Schacht's Contribution to the Study of Islamic Law," Bulletion (British Society for Middle Eastern Studies), Vol. 9, No. 2, 1982: pp. 132-140; Akh. Minhaji, Kontroversi Pembentukan Hukum Islam: Kontribusi Joseph Schacht (Yogyakarta: UII Press, 2004); Faisar Ananda Arfa, Sejarah Pembentukan Hukum Islam: Studi Kritis tentang Hukum Islam di Barat (Jakarta: Pustaka Firdaus, 1996).

${ }^{17}$ Joseph Schacht, “An Introduction to Islamic Law”, p. 1. 
the world's religions, law occupies a distinctively important position in Islam, a position possibly no less important than in the religious tradition of Judaism." 18

The position of Islamic law in Islam is very important for those who embrace this religion. Muslims are expected to study how to apply Islamic law in daily life. According to Akh. Minhaji, it is not an exaggeration to say that "there is no subject more important for students of Islam than what is usually called Islamic law."19 Minhaji has compiled the interpretations of scholars who discussed the importance of law in Islam. First, Islam is a religion of law. Second, law is the distilled essence of the civilization of a people and since it reflects civilizations in general, there can be no doubt that is particularly true of the world of Islam. Third, it is impossible to understand the Muslim mind, Muslim society, Muslim ideals, politics, and reactions without some knowledge of that law, which still molds and pervades them all. Fourth, law is the heart of Islam; this is a proposition that has been generally accepted within the ranks of the unbelievers as well as believers, and it forms the basis of much of Islamic scholarship. Fifth, for many devout Muslims, traditionalist and modernist alike, Islam without the law is unimaginable. Sixth, the shari was a way of life, which for Muslims constituted the core of Islam. Seventh, it is impossible to understand Islam without understanding Islamic law. Eigth, Islamic law will always remain one of the most important, if not the most important, subjects of study for the student of Islam. ${ }^{20}$

From the statements above, it can be argued that Islamic law comprises the whole aspect of Islamic teaching. Unfortunately, when we explore what really constitutes Islamic law, we encounter many different perceptions. Some questions are to be posed; when is Islamic law considered as shari When $^{2}$ is Islamic law considered as fiqh? As Mashood A. Baderin notes, "Islamic law, strictly speaking, is not monolithic. Its jurisprudence accommodates a pluralistic interpretation

\footnotetext{
18 Zafar Ishaq Ansari, "Foreword," p. v.

19 Akh. Minhaji, "Editorial: A Problem of Methodological Approaches to Islamic Law Studies," p. iv.

20 Akh. Minhaji, Ahmad Hassan and Islamic Legal Reform in Indonesia (1887-1958), pp. 2021; idem, "Reorientasi Kajian Ushul Fiqh," pp. 23-24.
} 
of its sources, thereby producing differences in juristic opinions that can be quite significant in a comparative legal analysis." 21

The terms fiqh and sharith have similar meanings. Fiqh is used in the literal sense to mean "understanding" (al-fahm). ${ }^{22}$ Basically, the meaning of the term figh is usually similar to words such as ilm (knowledge) and kalam (theology). ${ }^{23}$ The term 'ilm has the same meaning, and in the era of the Prophet, there appears to have been no difference between the two terms. ${ }^{24}$ According to Imran Ahsan Khan Nyazee, "as sophistication crept in, the term 'ilm came to be applied in a narrow sense to mean knowledge that comes through report, that is, traditions: hdd and ar The term fiqh ... came to be used exclusively for knowledge of the law." 25 Thus, the terms "ilm and fiqh were separated when specialization in law and tradition came into existence toward the end of the first century of Hijrah. ${ }^{26}$

Furthermore, the terms kala $x$ and fiqh were not separated until the time of al-Ma'mun (d.218 A.H.). During this time figh constituted both theological problems and legal issues. ${ }^{27}$ That is why Abu Hanifah (d. 150 A.H.) defined fiqh as márifah al-nafs ma>laha $>$ wa ma>alayba $>$ (understanding the self in terms of one's rights and duties). ${ }^{28}$ This means that figh concerns understanding Muslims' rights and obligations. However, when the Mu'tazilah ${ }^{29}$ began to use the term kalam for their teaching, the term figh came to be restricted to the corpus of Islamic law. This differentiation has serious implications for the study of Islamic law.

${ }^{21}$ Mashood A. Baderin, International Human Rights and Islamic Law, p. 33.

22 Abdul Azis Dahlam et al. (eds.), Ensiklopedi Hukum Islam, I, pp. 333; Kamaruzzaman Bustamam-Ahmad, Islam Historis: Dinamika Studi Islam di Indonesia, p. 224.

23 See, A. Qodri Azizy, Ekletisme Hukum Nasional, pp. 2-4.

${ }^{24}$ Imran Ahsan Khan Nyazee, Theories of Islamic Law, pp. 20-21; Ahmad Hassan, Pintu Ijtihad Sebelum Tertutup, trans. by. Agah Garnadi (Bandung: Pustaka, 1994), p. 5.

25 Imran Ahsan Khan Nyazee, Theories of Islamic Law, p. 21.

${ }^{26}$ Ahmad Hassan, Pintu Ijtihad Sebelum Tertutup, pp. 4-5.

${ }^{27}$ Imran Ahsan Khan Nyazee, Theories of Islamic Law, p. iv.

28 Abdul Azis Dahlan et.al. (eds.), Ensiklopedi Hukum Islam, 333. For detailed of Abu Hanifah, see Ahmad Syurbashi, Al-Aimmah al-Arba'ah (Beyrouth: Dar al-Jil, n.d.), pp. 14-68.

29 On Mu'tazilah, see George F. Hourani, "Islamic and Non-Islamic Origins of Mu'tazilite Ethical Rationalism", International Journal of Middle East Studies, Vol. 7, No. 1, 1976, pp. 59-87. 
There are many definitions of fiqh. 'Abdul Wahhab al-Khallaf

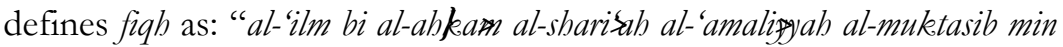
adillatiba $\rightarrow$ l-tafsi) conduct that have been derived from specific evidence)." "30 Al-Khallaf also highlights another definition of figh as: "majmu

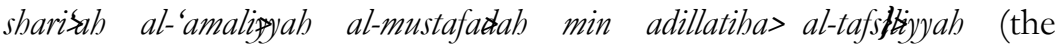
compilation of the legal rules pertaining to conduct that have been derived from specific evidence)." 31 Abu Ishaq al-Sirazi defined figh as:

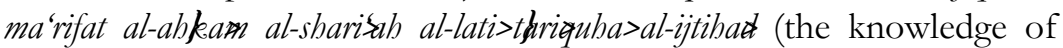
legal rules that derived by the process of ijtibat. ${ }^{32}$ It also can be defined as a "statement concerning the understanding of the speaker of the meaning of his speech" (ibarath 'an fahmi gharadhi al-mutakallimu min kalaraibi). ${ }^{33}$ It is perhaps safe to say that fiqh is the finding of Islamic law from the main sources (the Qur'an and Sunnah) through ijtihate.

The term sharith means the source of drinking water. ${ }^{34}$ For the Arabs, shari means religion, al-thripath al-mustaqiatah (the right way), and al-nusis\} 3al-muqaddas (sacred texts) from the Qur'an and Sunnah. ${ }^{35}$ Schacht says that shari is "the sacred law of Islam. "He goes further, by stating". It is an all-embracing body of religious duties, the totality of Allah's commands that regulate the life of every Muslim in all aspects; it consists of ordinances regarding worship and ritual, as well as political and (in the narrow sense) legal rules." 36

In other cases, scholars differentiate between shari and figh. First, while shari comes from Allah, figh is the product of human interpretation. Second, there is only one sharith, while figh implies

\footnotetext{
30 Abdul Wahhab Khallaf, Ilm Ushûl al-Fiqh (Beirut: Dar al-Qalam, 1978), p. 11. This may translated into English as: the knowledge of the shari abłâm (legal rules), pertaining to conduct, that have been derived from their specifis evidences.

31 Abdul Wahhab Khalaf, Tlm Ushul al-Figh, p. 12.

32 Abu Ishaq al-Syirazi, al-Luma fi Ushul al-Fiqh (Cairo: Muhammad Ali Sabih, 1900), p. 4 as qouted by A. Qodri Azizy, Ekletisme Hukum Nasional, p. 13.

33 Akh Minhaji, Abmad Hassan and Islamic Legal Reform in Indonesia (1887-1959) (Yogyakarta: Kurnia Kalam Semesta Press, 2001), p. 94.

34 Abdul Azis Dahlan et.al. (eds.), Ensiklopedi Hukum Islam, p. 335.

35 Ibid. For Sunnah, see Muhammad Abdul Rauf, "Al-Hadith: Its Authority and Authencity", IIU Law Journal 1 (1) 1989, pp. 1-50.

${ }^{36}$ Joseph Schacht, An Introduction to Islamic Law, p. 1.
} 
diversity. Third, shari is very authoritative while fiqh is very liberal, since it is a human product. Fourth, shari is not subject to change; on the contrary, figh faces many changes through socio-cultural dynamics. Fifth and finally, shari is idealistic while figh is realistic. ${ }^{37}$

It is noteworthy when I speak about Islamic law I am referring to fiqh, not shariah. In this context, fiqh as human interpretation has produced Islamic law or the Islamic legal system. There are at least four types of Islamic legal literature: kutub al-fiqhiłzah (books on Islamic jurisprudence), decrees of the Islamic courts, laws and regulations by Muslim countries, and fatwa legal pronouncements of jurists). ${ }^{38}$ In this case, the application of Islamic law in Aceh falls into the category of laws and regulations by a Muslim country.

Moreover, the development of Islamic law, as Minhaji states, passed through three periods. ${ }^{39}$ The first period, in the seventh century C.E is usually called the formative era, ${ }^{40}$ during which Islamic law was very flexible and adapted itself to the local customs of societies. The second period dates from approximately the fourteenth century, when Islamic law was supposedly expounded definitively by the orthodox legal schools (i.e. Maliki, Hanafi, Syafi'i, and Hanbali), and when Muslims throughout the central Islamic lands elected to follow one of these four schools. In this era, Islamic law was considered to have become immutable. Consequently, it became increasingly rigid and static, a phenomenon that eventually resulted in the controversial notion of insidacbal-ijtihat or the closing of the gate of creative legal reasoning. ${ }^{41}$ This era ended at the end of the nineteenth century C.E.,

37 See Kamaruzzaman Bustamam-Ahmad, "Kontribusi Daerah Aceh terhadap Perkembangan Awal Hukum Islam di Indonesia," Al-Jarri’ah, No.64 (1999), p. 148.

38 M. Atho Mudzhar, "Social History Approach To Islamic Law," Al-Jarziah, No. 61, 80 (1998); M. Atho Mudzhar, "Dirâsat al-Ahkâm al-Islâmiyyah bin Mandhûr 'Ilm alIjtimâ", Al-jarrìah, No. 65 (2000), p. 177.

39 Akh Minhaji, Abmad Hassan (2001), pp. 13-15; idem, "Modern Trends in Islamic Law: Notes on J.N.D. Anderson's Life and Thought," Al-Jarriah, 39 (1) 2001, pp. 8-9. 40 On the formative era, see generally Wael B. Hallaq, A History of Islamic Legal Theories, pp. 1-35.

41 On this, see Wael B. Hallaq, "Was the Gate of Ijtihad Closed?", International Journal of Middle East Studies (16) 1984, pp. 3-41; idem, "On the Origins of the Controversy about the Existence of Mujtahids and the Gate of Ijtihad," Studia Islamica (63) 1986, pp. 129-141. 
when the Islamic nation-state began to emerge, ${ }^{42}$ along with growing consciousness of the need for legal reform. The third and current stage of development arose out of an impression on the part of scholars that they were unable to resolve new legal problems with the aid of classical Islamic law. ${ }^{43}$

To resolve legal problems in modern life, Muslims need to reform Islamic law. Consequently, many Muslim countries have adopted one of three models, as I stated in earlier. The reformers were compelled to search for methods in which Islamic law could be interpreted, modified, and applied to meet the needs of modern society. ${ }^{44}$ For the most part, Islamic law reform has been actively enacted only in the

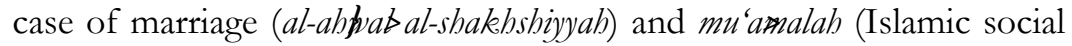
affairs). According to Mudzhar, there are two broad types of Islamic law reform. The first, intra-doctrinal reform, combines many types of Islamic legal thinking. The second, extra-doctrinal reform, gives new interpretations to Islamic texts. ${ }^{45}$ These methods of reform, widely used in contemporary Muslim societies, according to Anderson as quoted by Minhaji, manifest themselves through five methods.

First, procedural expediency is a method that has given a much wider and more significant application to the principle of takbsizal-qada $>$ the right of the ruler to define and confine the jurisdiction of the courts. Second, eclectic expediency is known in Arabic as takbayyur, that is, a suitable viewpoint selected from amongst various opinions in order to full fill the needs arising from new demands of Muslim society. Third, the expedient of re-interpretation has been used by reformers to re-interpret the classical texts in emphasizing the importance of practicing ijtihat Fourth, administrative regulation seems to be the basis for all previous methods. Fifth, reform by juridical decision is a

\footnotetext{
${ }^{42}$ See generally, Robert W. Hefner, Civil Islam: Muslim and Democratization in Indonesia (Oxford: Princeton University Press, 2000), pp. 3-7.

43 See also Bassam Tibi, Islam and the Cultural Accomodation of Social Change, trans. by. Clare Krojzl (Boulder, CO: Westview Press, 1991), pp. 64-65; R. Stephen Humphreys, Islamic History: a Framework for Inquiry (New Jersey: Princenton University Press, 1991), pp. 210-212.

44 Akh. Minhaji, Modern Trends in Islamic Law, p. 13.

45 M. Atho Mudzhar, Membaca Gelombang Ijtibad: Antara Tradisi dan Liberasi (Yogyakarta: Titian Ilahi Press, 1998), p. 177.
} 
method by which the application of Islamic law made by a series of judicial decisions. ${ }^{46}$

\section{A Brief Overview on Aceh}

Nanggroe Aceh Darussalam is located in the northern-most part of Sumatra, or in the western-most part of the archipelago of 17,000 islands that make up Indonesia. It covers an area of 57.365,57 square kilometers, ${ }^{47}$ with a population of 3.929 million. ${ }^{48}$ The composition of population based on religious affiliation is as follows: Muslims (97 percent), Christians (2. 3 percent), Hindus (0.01 percent), Buddhists (0.37 percent), and others (0.02 percent). ${ }^{49}$ The most densely populated area is Banda Aceh (3.010 people $/ \mathrm{km}^{2}$ ) while West Aceh is sparsely populated (13-18 people $\left./ \mathrm{km}^{2}\right)$. Aceh is home to numerous ethnic groups: the Acehnese, who comprise the largest group, live on the coastal areas to the hinterland; the Gayo, in Central and Southeast Aceh; the Aneuk Jame, in West Aceh, the southern part of South Aceh down to coastal areas bordering North Sumatra, and on the east coast of Banyak island; the Singkel, southeast of South Aceh; the Kluet, in the central of South Aceh; the Alas, south of Southeast Aceh; the Pulau, on Seumeulu Island; and the Tamiang, south of Aceh.

Aceh is rich in oil and natural gas, accounting for 13 per cent of Indonesia's oil production. The P.T. Arun oil fields generate US\$ 4 million a day, nearly all of which goes to Jakarta. Its qualified natural gas is partly owned by Mobil Oil Corporation ( 35 percent), and partly by the Indonesian state company Pertamina ( 55 percent). Aceh is also said to be the second largest producer of marijuana in Southeast Asia, which is almost entirely for export, and all sides of the armed conflict are said to be involved in this trade. ${ }^{50}$

Over the course of Aceh's history, interaction with foreigners, including Indians, Chinese, Arabs, and Europeans, has brought about

\footnotetext{
46 Akh Minhaji, Modern Trends in Islamic Law, pp. 13-17. See also J.N.D. Anderson, Islamic Law in the Modern World (Connecticut: Greenwood Press, 1959).

47 Sutedjo Sujitno and Mashud Achmad, Aceh: Past, Present, \& Future (Banda Aceh: Kantor Gubernur, 1995), p. 30.

${ }^{48}$ Leo Suryadinata et al., Penduduk Indonesia: Etnis dan Agama dalam Era Perubahan Politik (Jakarta: LP3ES, 2004), p. 159.

${ }^{49}$ Ibid., p. 161.

50 ICG Indonesian Briefing Paper, “Aceh: Escalating Conflict”, 7 December, 2000, p. 2.
} 
lasting influences not only in terms of culture but also in the physical appearance of the people. If we travel through this region we will also encounter many models of cultures and traditions, some of which were adopted from Indian and Arab traditions. Similar to Kelantan, Aceh ${ }^{51}$ is a major gateway of Islamic studies in Southeast Asia, and is known as the Serambi Mekekah (Verandah of Mecca) in Indonesia. ${ }^{22}$ The process of islamization in Aceh is important to be understand because it sheds light on the position of Islam in Southeast Asia, especially in Indonesia. ${ }^{53}$ There are many theories about the coming of Islam to Aceh. Most scholars agree that it arrived, not in the thirteenth century AD from Gujarat, but as early as the seventh century AD from Saudi Arabia. ${ }^{54}$ Karel A. Steenbrink, an Indonesianist from the Netherlands who has written several books on Indonesia, says before the thirteenth century AD many "Muslims came to Indonesia" and "Indonesians embraced Islam." 55 According to this source, before the thirteenth century most Acehnese had already become Muslim through contact with travelers from the Middle East and South Asia.

There are many reasons why the spread of Islam became noticeable in and around Aceh. According to Yusny Saby, Arab merchants happened to control the trade routes in the Indian Ocean long before the birth of the Prophet, and thus they facilitated the spread of Islam later. Personal contacts also played an important role in the islamization process. ${ }^{56}$ In Aceh many Arab travelers married Acehnese women, and in this way, contact with the indigenous

51 About the name of Aceh, see Aboebakar Atjeh, "Tentang Nama Aceh," in Ismail Suny (ed.), Bunga Rampai tentang Aceh (Jakarta: Bhratara, 1980), pp. 15-26.

52 On this see S.M. Amin, "Sejenak Meninjau Aceh, Serambi Mekkah," in Ismail Suny (ed.), Bunga Rampai, pp. 45-102.

53 See Amran Kasimin, Religion and Social Change Among the Indigenous People of the Malay Peninsula (Kuala Lumpur: Dewan Bahasa dan Pustaka Kementerian Pendidikan Malaysia, 1991), pp. 150-152; Azyumardi Azra, Renaisans Islam Asia Tenggara: Sejarah Wacana \& Kekuasaan (Bandung: Rosdakarya, 1999), p. 41. See also, Anthony Reid, "Introduction," in Anthony Reid (ed.), The Making of an Islamic Political Discourse in Southeast Asia (Victoria: Center of Southeast Asia, 1993), pp. 1-16.

${ }^{54}$ Kamaruzzaman Bustamam-Ahmad, "Kontribusi Daerah Aceh terhadap Perkembangan Awal Hukum Islam di Indonesia”, Al-Jarri'ah, No. 64, 1999, pp. 150-154.

55 Karel A. Steenbrink, Beberapa Aspek Tentang Islam di Indonesia Abad ke-19 Jakarta: Bulan Bintang, 1984), p. 4.

56 Yusny Saby, Islam and Social Change: The Role of Ulama in Acehnese Society", Ph.D. Dissertation. Temple University, 1995, p. 18. 
population became even closer. ${ }^{57}$ However Atho Mudzhar argues that despite the fact that visiting Arab, Persian, and Indian merchants played a crucial role in commercial relations, their contribution to the introduction of Islam in the region was limited. ${ }^{58}$ In his opinion, the actual dissemination of Islam among the local people and their mass conversion to Islam were due to the untiring efforts of Indian, particularly Bengali, Sufi (mystic) preachers who accompanied the merchants on their visits to the local rulers. ${ }^{59}$

Aceh attracted traders from the East and West for its pepper and other spices; in addition, its sultans' patronage of religious teaching caused the court to be surrounded by learned scholars. ${ }^{60}$ This means that learned scholars have played an important role in Aceh, especially for the Islamic kingdoms. Historically, the ulama in Aceh always served as advisors for the rulers in the role of mufti or qadhi malikul adil. Moreover, in 1582 two scholars from Mecca reportedly arrived in Aceh, and at about the same time there came from Gujarat a Shaykh Muhammad Jaylani, who was a popular teacher of logic, rhetoric, and jurisprudence. To meet the demand for guidance in mysticism, he left several years to study in Mecca, returning to Aceh afterwards. ${ }^{61}$ Nurdin Ar-Raniri in Busta $>$ al-Sala however, tells a slightly different version of the story in which the arrival occurred not in 1582, but in 1580 and the names of the scholars are Shaykh Abu al-Khayr ibn Ibn Hajar and Shaykh Muhammad Yamani. The former was the author of Al-Sayf alQati $>$ a book dealing with Sufi thought concerning the problematic nature of the third metaphysical category between being and nonbeing: (the fixed essences). Shaykh Muhammad al-Yamani taught the science of the sources (al-usis) that is, the sciences relating to the Holy Qur'an; the Tradition of the Holy Prophet (al-Sunnab); the Consensus

\footnotetext{
${ }^{57}$ Yusny Saby, Islam and Social Change, p. 20.

58 Mohammad Atho Mudzhar, Fatwa-Fatwa Majelis Ulama Indonesia, Jakarta: INIS, 1993), p. 15.

${ }^{59}$ Ibid.

60 A. Mukti Ali, An Introduction to the Government of Acheb's Sultanate (Yogyakarta: Jajasan Nida, 1970), p. 7.

${ }^{61}$ Ibid.
} 
of Opinion or Agreement (al-ijma , and the traditions relating to the Companions (al-a ar.62

It should be pointed out that in Aceh Islamic teaching was limited to Sufism issues and serious implications of Islamic thought. Consequently, before Nurdin Ar-Raniri came to Aceh, the most prominent issues still concerned with mysticism. The ulama in Aceh who concerned with Sufism were Hamzah Fansuri (1550-1600) and Syamsuddin As-Sumatrani (d. 1629). ${ }^{63}$ The former, who lived in Barus on the west coast of northern Sumatra was said to be the greatest Malay Sufi poet and the first man to translate Sufi doctrines and metaphysics into Malay, and his probable disciple, Syamsuddin alSumatrani, was considered as Shaykh al-Isla of Aceh. He advised the sultan on religious and cultural matters and also acted on his behalf in diplomatic and international affairs. ${ }^{64}$ But when Nurdin Ar-Raniri returned to Aceh in 1637, he was appointed as the Shaykh al-Isla during the Sultanate of Iskandar Sani who was against the doctrine of wijuyah, and advised the sultan to burn the works of Hamzah Fansuri. 65

In the seventeenth century A.D., four queens reigned over Aceh in succession, and in the eighteenth century sultans of Arab blood (Sayyid) came to the throne.66 Before they reigned, from 1607 to 1637, Aceh was ruled by Sultan Iskandar Muda, a vigorous and conquering ruler who subjugated Deli (1610), Johor (1613), Pahang (1616), Kedah (1619), Perak (1620), and Nias (1624), and attempted to re-conquer Malacca (1626).67 Iskandar Muda is credited with having brought

\footnotetext{
62 Syed Muhammad Naquib Al-Attas, A Commentary on the Hujjat al-Siddiq of Nur al-Din al-Raniri (Kuala Lumpur: Ministry of Culture Malaysia, 1986), p. 5.

63 See also Oman Fatahurahman, Tanbîh al-Masyî, Menyoal Wabdatul Wujud: Kasus Abdurrauf Singkel di Aceh Abad 17 (Bandung: Ecole Francaise D'extreme-orient and Mizan, 1999).

${ }^{64}$ Syed Muhammad Naquib Al-Attas, A Commentary on the Hujjat al-Siddiq, p. 6.

${ }^{65}$ See Peunoh Daly, Hukum Perkawinan Islam: Suatu Studi Perbandingan dalam Kalangan Ablus-Sunnah dan Negara-negara Islam (Jakarta: Bulan Bintang, 1988), pp. 28-29.

66 A. Mukti Ali, An Introduction to the Government, p. 7.

${ }^{67}$ On this see Denys Lombard, Kerajaan Aceb: Jaman Sultan Iskandar Muda (1607-1636), trans. By Winarsih Arifin (Jakarta: Balai Pustaka, 1986); Syed Muhammad Naquib AlAttas, A Commentary on the Huijat al-Siddiq..p. 7; Lee Kam Hing, The Sultanate of Aceh: Relations with te British 1760-1824 (Kuala Lumpur: Oxford University Press, 1995), pp. 14-15; Yusny Saby, Islam and Social Change, pp. 32-39.
} 
Islamic reforms to Aceh and promulgating the statutes that would make Aceh an Islamic state. ${ }^{68}$ In addition, he also attached himself and his kingdom to the consultation of the ulama. ${ }^{69}$

The collaboration between the ulama and rulers brings about the implementation of Islamic law. Sultans appointed ulama to be the mufti or qadbi malikul adil. Hamzah Fansuri served Sultan 'Ala al-Din Ri'ayat Shah Sayyid Mukammal (1588-1604). Shamsuddin al-Sumatrani served at the court of Sultan Iskandar Muda until his death. Nurdin Ar-Raniri, during his tenure at the Acehnese court, also functioned as the political advisor to the ruler, Sultan Iskandar Muda. Saby points out,

Nurdin was the first 'a in Aceh Darussalam to give a fatwa on the legitimacy of women as rulers. He defended his position vigorously against the opposition of the 'ulama of the Hijaz, to whom the most crucial religious problems were referred. Nurdin's stand on this matter is historic, yet it remains controversial. ${ }^{70}$

Finally, Abdur Rauf Singkel was appointed as qadhi for Sultan Taj al-'Alam Safiyatuddin Shah. As mentioned above, he dedicated his book on Islamic jurisprudence, entitled Mir'at al-Tullals to Sultan Taj al-Alam Safiatuddin Shah. ${ }^{71} \mathrm{He}$ also served the court and validated the shari ruling regarding the legitimacy of female rulers in Aceh. Without his approval, female succession could have been jeopardized. ${ }^{72}$ However, in the sixteenth century the mufti of Mecca in the name of Islamic law and orthodoxy issued a fatwa that forbade women from attaining the position of sultan. ${ }^{73}$

It is safe to say the ulama of the Aceh Sultanate regarded themselves as free to interpret the shari according to their assessment of the needs of the time and the particular situation. ${ }^{74}$ In fact, the intervention of Mecca through the fatwa rigidified Islamic legal thought

\footnotetext{
68 Syed Muhammad Naquib Al-Attas, A Commentary on the Hujjat al-Siddiq, p. 7.

${ }^{69}$ Yusny Saby, Islam and Social Change, p. 32. See also idem, "The Ulama in Aceh: A Brief Historical Survey," Studia Islamika, Vol. 8, No. 1, , 2001 pp. 1-54.

${ }^{70}$ Yusny Saby, Islam and Social Change, p. 68.

${ }^{71}$ Azyumardi Azra, Menuju Masyarakat Madani: Gagasan, Fakta, dan Tantangan (Bandung: Rosdakarya, 1999), p. 29.

72 Yusny Saby, Islam and Social Change, p. 72.

73 Azyumardi Azra, Menuju Masyarakat Madani, p. 29.

${ }^{74}$ Yusny Saby, Islam and Social Change, p. 72.
} 
in Aceh. The polemic in Aceh was not based on Islamic teaching, but only on political interests. It was apparent to most that such a fatwa could have been issued while Abdur Rauf Singkel was in office; those who opposed having women as rulers appear to have waited for his death, and they acted promptly. ${ }^{75}$

The ulama, besides serving as mufti or qadhi malikul adil, also wrote many books. The first book on figh in Indonesia, Siratal-Mustaqi ras, was written by Nurdin ar-Raniri. ${ }^{76}$ Composed in Malay, this work was begun in 1634 and completed seven years later. It deals with the science of practical judgments pertaining to religious practice (figh), but treats only those aspects concerned with devotional duties (al-ibaltr. Practical duties (al-mu'arala were treated later by 'Abdur Rauf Singkeli (d.1639) in his Mir'at al-Tullal In addition, this book was printed in the margin of the Sabi al-Mubtadi $>$ of Muhammad Arshad in Mecca in 1892, and reprinted many times. ${ }^{77}$ Indeed, it was written by Nurdin at the request of Sultan Iskandar Sani who wanted the Acehnese people to know about Islamic law. Another book is Mir'at al-Tullal by Abdur Rauf Singkeli, which, according to Azyumardi Azra, "is the first book in Malay-Indonesian dealing with Fiqh al-mu'arzalat and concerning social, political, economic, and religious aspects of Muslim life."78 There is also a book of figh, a compilation of fatwas, entitled Mubimmas al-Nafa fi ayaras'ilat al-hoddi (the precious gems explaining questions about currents topics). According to B.J.O. Schrieke, as qouted by Nico Kaptein, Mubimmatal-Nafa is an Arabic Malay collection of fatwas published in Mecca in $1912 \mathrm{AD}$ by the Acehnese 'Abd al-Salam ibn Idris; it discusses the issues submitted by Indonesians to the authority of the Meccan experts during the previous half century. ${ }^{79}$

During the early seventeenth century many Acehnese went to Mecca both to perform the haßł and to study; as a result, the Haramayn connection became important for Acehnese people. Anyone who

\footnotetext{
75 Ibid.

${ }^{76}$ Martin van Bruinessen, Kitab Kuning Pesantren dan Tarekat: Tradisi-Tradisi Islam di Indonesia (Bandung: Mizan, 1999), p. 113.

77 Syed Muhammad Naquib Al-Attas, A Commentary on the Huijat al-Siddiq, p. 25.

78 Azyumardi Azra, "Tanbi al-Masyi; Otentisitas Kepakaran Abdurrauf Singkel," in Oman Fathurrahman, Tanbi Al-Masyi (Bandung: Mizan, 1999), p. 15.

79 Nico Kaptein, The Muhimmat al-Nafa'is: A Bilingual Meccan Fatwa Collections for Indonesian Muslims From the end of the Nineteenth Century (Jakarta: INIS, 1997), p. xii.
} 
studied in Mecca went back to Aceh to teach at dayah, ${ }^{80}$ where students learned Islamic teachings, especially Islamic law; they eventually became the ulama in the archipelago. For centuries the ulama of Aceh have obtained their knowledge of religion from traditional religious schools, that is, from meunasab rangkang bale (small places for studying Islam in villages).

\section{Sharimh and Adat Law in Aceh}

By and large, the people of Aceh believe that adat and shari should take their places side by side in their country. ${ }^{81}$ C. Snouck Hurgronje quotes Acehnese proverbs that say, "Hukum (law) and adat are inseparable, even as God's essence and his attributes," and "Hukum and adat are like the pupil and the white of the eye; the bukum is Allah's bukum and the adat Allah's adat." 82

Both adat and shari became sources for implementation of Islamic law for the Acehnese people. In Acehnese society, adat is seen as a way to understand and to implement shari ${ }^{2} .^{83}$ Before the coming of Islam, the Acehnese were influenced by Hinduism and Buddhism. ${ }^{84}$ After Islam arrived in the region, it replaced these traditions with Islamic teachings. And the counterparts to adat that control the lives of Muslims in other parts of the Islamic world, such as the Bedouins of Arabia, the Egyptians, the Syrians, are for the most part different from those of the Acehnese, Indonesians, and Malays. The relationship of these local traditional laws to the law of Islam, however, and the tenacity with which they maintain themselves, are similar..$^{85}$

\footnotetext{
80 About dayah in Aceh, see M. Hasbi Amiruddin, Ulama Dayab: Pengawal Agama Masyarakat Aceh, trans. by Kamaruzzaman (Lhokseumawe: Nadiya Foundation, 2003).

81 A. Mukti Ali, An Introduction to the Government, p. 22. See also J.F. Holleman (ed.), Van Vollenhoven on Indonesia Adat Law (The Hague: Koninklijk Instituut Voor Taal-, Land en Volkenkunde, 1981), pp. 54- 122.

82 C. Snouck C. Hurgronje, The Acehnese (Leiden: E.J. Brill, 1906), p. 72.

${ }^{83}$ Ismuha, "Ulama Aceh Dalam Perspektif Sejarah", in Taufik Abdullah (ed.), Agama dan Perubahan Sosial (Jakarta: Raja Grafindo Persada, 1996), p. 6; idem, "Adat dan Agama di Aceh", Working Paper No. 16 (Darussalam: Pusat Latihan Penelitian Ilmuilmu Sosial, 1983), p. 9.

${ }^{84}$ See Luthfi Auni, The Declince of the Islamic Empire of Aceh", M.A. Thesis, McGill University, 1993, pp. 8-9.

85 A. Mukti Ali, An Introduction to the Government, 1970, p. 24. For Indonesian context, see Ratno Lukito, Islamic Law and Adat Encounter: The Experience of Indonesia (Jakarta:
} 
Furthermore, adat plays an important role in Acehnese society. The administration of the kampong (village) is ruled by the adat system based on shari the kampong is administered by three offices, namely, the keuchik, the teungku, and the ureung tuba. The keuchik is the headman, and the Acehnese used to call him "the father of the kampong." 87 The teungku is "the mother of the kampong," 88 and Mukti Ali states that although the keuchik devotes himself more particularly to maintain the adat, the promotion of godly living among his people is also regarded as part of his duty. Consequently, the upholding of the bukum is the teungku's specialty, although a knowledge of and regard for the adat are also regarded as indispensable. ${ }^{9}$ The ureung tuba, which is the equivalent of "elders" are the men of experience, worldly wisdom, good manners, and knowledge of adat in the kampong. They are generally persons who have reached a certain age, but a younger man who displays these characteristics is equally eligible to be an ureung tuha. ${ }^{90}$

In the daily life of the society, these leaders work together in many ways according to Islamic teachings. The center of these activities is the meunasa (Ar. madrasa), which the place of prayer and Islamic education..$^{91}$ The meunasa also serves as a sleeping place for men, a rest house for strangers, and a place of assemblage on various special occasions. It is there that the affairs of the kampong are debated, village festivals held, contracts of marriage concluded, etc. ${ }^{92}$

It is safe to say that shari and ad in Aceh are in harmony with one another, since all Acehnese people believe adat is part of shari not against it. This system only became subject to question when the Dutch colonized Aceh and substituted it with their own system. Dutch

Logos, 2001); idem, "Law and Politics in Post Independence Indonesia: A Case Study of Religious and Adat Courts", Studia Islamika, Vol. 6, No. 2, 1999, pp. 63-86.

${ }^{86}$ See generally, Snouck. C. Hurgronje, Aceb: Rakyat Adat dan Adat Istiadatnya, trans. by Sutan Maimoen (Jakarta: INIS, I, 1997), pp. 67-91.

${ }_{87}$ Taufik Abdullah, Islam Masyarakat: Pantulan Sejarah Indonesia (Jakarta: LP3ES, 1996), p. 168.

88 Ibid., p. 12.

89 A. Mukti Ali, An Introduction to the Government, p. 12.

90 Ibid., p. 13.

${ }^{91}$ See also Yusny Saby, Islam and Social Change, p. 110.

92 A. Mukti Ali, An Introduction to the Government, p. 14. 
scholars like Hurgronje maintain that adat should be separated from shari because adat belongs to ulee balang or umara (leaders) and shari belongs to ulama. The Dutch in fact promoted adat while at the same time trying to eliminate the implementation of Islamic values. ${ }^{93}$ As a result, the Dutch paid attention only to the ulee balang, not to ulama. The consequence of this strategy is that sharit is seen as different from adat. Secularization began in Aceh when Hurgronje suggested that religion and politics be separated.

\section{The Nature of Conflict and the Issues}

The implementation of Islamic law in Aceh before the coming of European colonialists went well. After the Europeans arrived in Aceh, they substituted their law in replacement for the traditional and legal system in Aceh. The Portuguese entered Aceh with their mission of spreading Christianity in the archipelago. According to Lutfhi Auni, the religious response of the Acehnese to the Portuguese is difficult to ascertain since there is no single work of the sixteenth century ulama of Aceh on that matter. ${ }^{94}$ Furthermore, the discourse of Islamic law or Islamic teachings becomes questionable when the Dutch arrived in Aceh. Hurgronje writes:

At the time of the coming of the Dutch to Aceh there were numerous schools throughout the country; and it is a notorious fact that on more than one occasion the students from these schools threw themselves, practically unarmed, upon the bayonets of the Dutch troops.

These were youths inflamed to fanaticism by the teaching they had imbibed in regard to the holy war and the reboundless recompence here after awaiting the martyr to his creed, without his being called on to render further account of his actions in this world. In estimating their contempt for death, however, we must reflect upon the fact that at that time the most fearful rumours were current in Acheh as to the tortures which would be the lot of anyone who fell alive into the hands of the kafirs. ${ }^{95}$

\footnotetext{
93 Akh. Minhaji, “Ahmad Hassan and Islamic Legal Reform in Indonesia (1887-1959)", p. 51.

94 Amirul Hadi, "Aceh and the Portuguese: A Study of the Struggle of Islam in Southeast Asia," Thesis, M.A., McGill University, 1992, p. 81.

${ }^{95}$ C. Snouck C. Hurgronje, The Acehnese, p. 166.
} 
As for the elimination of Islamic law, Hurgronje acknowledges the theory of receptie that Islamic law could only be effective and binding upon Indonesian Muslims if it were consistent with or derived from customary law, the adat. The living law for Indonesian people was, therefore, seen as being rooted not in religious law but rather in customary law. ${ }^{96} \mathrm{He}$ says that the domestic institutions of that area are the main reasons for conflict with religious law.

After independence on August 17, 1945, Aceh became a part of Indonesia. In this context, the Indonesian government headed by Sukarno declared that Indonesia is not an Islamic state and would not implement Islamic law. ${ }^{97}$ The reason he gave was that the Indonesian archipelago is inhibited by various ethnic, social, religious, and cultural groups, each of whom retains their customs and ways of life. Embracing this pluralism, the Republic of Indonesia coined the official motto: "Bhinneka Tunggal Ikea," or "Unity in diversity."

In the post-colonial era, several groups of laws survived the transition from the Dutch colonial government: (1) laws governing all inhabitants, e.g. the law on industrial property and patents; (2) customary law, which applied to indigenous Indonesians; (3) Islamic laws applicable to all Indonesian Muslims; (4) laws tailored to specific communities in Indonesia, such as the marriage law for Indonesian Christians; and (5) the Burgelijk Wetboek and the Wetboek van Koophandel measures, originally applied to Europeans only, but later extended to cover the Chinese. ${ }^{99}$

After Indonesia's independence in 1945, Aceh was granted provincial status under a military governor. In 1951, Aceh was part of North Sumatra with the status of a residency. The people tried to regain the status of province, and in 1959 their aspiration materialized following a mission assigned by the prime minister to solve this problem. There was a legal basis related to the establishment of Aceh: first, Law No. 24, 1956 on the establishment of Aceh province;

\footnotetext{
${ }^{96}$ Akh. Minhaji, Abmad Hassan and Islamic Legal Reform, p. 56.

${ }^{97}$ See Saifuddin Anshari, "Islam or the Pancasila as the Basis of the State", in Ahmad Ibrahim et.al. (eds.), Readings on Islam in Southeast Asia (Singapore: ISEAS, 1985), pp. 221-228.

${ }_{98}$ Ratno Lukito, Islamic Law and Adat Encounter, 2001, pp. 76-77.

${ }_{99}$ Ratno Lukito, Law and Politics in Post Independence Indonesia, 1999, p. 69. See also, Daniel S. Lev, Islamic Courts in Indonesia: A Study in the Political Basis of Legal Institutions (Berkeley: University of California Press, 1972).
} 
second, a decree of the prime minister of the Republic of Indonesia, No.1/MISSI/1959 conferring special status upon the province of Aceh in relation to the exclusiveness of its religion, education, and traditions (adat); and, third, Law No. 574 on the Principle of Regional Administration (wherein the status of Aceh as a Special Region was confirmed). ${ }^{100}$

Daud Beureueh, the leader of DI/TII of Aceh, carried out a revolt against the Sukarno regime using a radical strategy. On September, 21, 1953, he declared that Aceh should be an Islamic state and should not be subject to Indonesian law or secular law. ${ }^{101}$ This rebellion ended when the Indonesian government sent Col. M. Jassin to persuade him to rejoin Indonesia. Eventually, Daud Beureueh agreed to rejoin and was exiled by the government to Jakarta. ${ }^{102}$ As a result, Aceh was given the status of special region, with the right to implement Islamic law in 1959. However, this promise, which had been approved by the government, was not implemented.

Unfortunately, the feeling of the Acehnese people that they are not a part of Indonesia still continues. The rebellion lead by Daud Beureueh inspired other groups which claim that Aceh is not part of Indonesia. In 1976, Hasan di Tiro, the president of Aceh Sumatra National Liberation Front (ANSLF), declared that Aceh should be an independent state. But he did not proclaim an Islamic state or the desire to implement Islamic law for Aceh. What he wanted to do in Aceh was to bring a classical nationalism to the Acehnese people. ${ }^{103}$

Another factor contributing to popular support for independence has been unhappiness over the unequal distribution of benefits from the large industrial enterprises and plantations along Aceh's east coast. The discovery of substantial reserves of natural gas near

\footnotetext{
100 Sutedjo Sujitno and Mashud Achmad, Aceh, p. 56.

101 See Herberth Feith and Lance Castles (eds.), Pemikiran Politik Indonesia 1945-1965 (Jakarta: LP3ES), pp. 209-210; also Taufik Abdullah, "Teungku Daud Beureueh: Pejuang Kemerdekaan yang Berontak" Tempo, 24 August, 2003, pp. 26-27; Hasanuddin Yusuf Adan, Tamaddun \& Sejarah: Etnografi Kekerasan di Aceh, Yogyakarta: Prismasophie), pp. 55-71.

102 Tempo, 24 August, 2003, p. 31.

103 See Anthony Reid, "Perlawanan dalam Sejarah Naggroe Aceh Darussalam", Tempo, 24 August, 2003, p. 39. For Hasan's view on Nationalisme, see Tengku Hasan di Tiro, "Nasionalisme Indonesia," in Yusra Habib Abdul Ghani, Mengapa Sumatera Menggugat, (Aceh: Biro Penerangan Acheh-Sumatra National Liberation Front, 2000), pp. 41-67.
} 
Lhokseumawe, Aceh Utara, in the early 1970s, led to the establishment of large extraction and processing facilities, as well as associated industries. ${ }^{104}$ This became one of the reasons for Hasan di Tiro's promotion of the idea of Aceh Merdeka. In fact, in 1976, Hasan di Tiro failed to win the tender contract at PT. Arun. As a result, "he saw that the benefits of this factory would not go the Acehnese people."105 As Hasan di Tiro wrote in The Price of Freedom,

I have had a medium of success in the business world because I had entrée to highest business and governmental circles in many countries... I have close business relationships with top 50 US corporations in the fields of petrochemicals, shipping construction, aviation, manufacturing and food processing industries. ${ }^{106}$

After returning to Aceh at the end of 1976, Hasan emerged at the military camp at Panton Weng, where he stayed November 1-29, 1976 and called on selected Acehnese leaders to meet him. "The first order of things," he said, "is to make the Acehnese opinion leaders understand the political process in which our people and our country are involved: we are in the process of being swallowed by the Javanese colonialists and being put to death as a nation, so that the Javanese can inherit our land." 107

Hasan's stance had major implications for the revival of Acehnese historical consciousness. He also gave certain Acehnese leaders and his followers his books so that they could understand Acehnese history. GAM viewed the Javanese as the "real Acehnese enemy," since they colonized Aceh following the Dutch. Soon the organization had spread throughout the country, especially on Sumatra. Hasan maintains that the people already knew that the Javanese were their enemy, but no one reported the matter to the Indonesian Javanese regime which they all detested. This situation demonstrates the gap between the people of Aceh, Sumatra and the "Indonesian-Javanese colonialist

\footnotetext{
104 Amnesty International, "Shock Therapy" Restoring Order in Aceh, 1989-1993", http://acehnet.tripod.com/shock.htmfx [accessed on Mon August 2002)

105 Interviews with Safwan Idris, July, 1999.

106 Tengku Hasan di Tiro, The Price of Freedom: the Unfinished diary of Tengku Hasan di Tiro (Aceh: National Liberation of Acheh Sumatra, 1984), p. 4.

107 Tengku Hasan di Tiro, The Price of Freedom, p. 10.
} 
regime". ${ }^{108}$ Hasan also contends that the Javanese Indonesia was an illegally constituted state that had been maintained by using terrorism as a national policy. ${ }^{109}$

In other cases through 1989 and 1990 the government and military authorities insisted that the violent disturbances in Aceh were the work of criminal gangs, and that they had no political motivation. Yet, the perpetrators were soon identified as members of the "Security Disruptors Movement" (Gerakan Pengacau Keamanan, GPK), a government-coined term generally used to describe rebel movements. ${ }^{110}$ In recent years, the government has also referred to GAM as an "armed civilian gang" (Gerombolan Sipil Bersenjata, GSB). ${ }^{111}$ In 2003, however, the government began labeling GAM as a "terrorist group." 112

While GAM has been in existence since 1976, only in the last three years has it developed a significant popular base, a steady source of arms, and a relatively well-organized command structure. ${ }^{113}$ The membership of its armed wing, Angkatan Gerakan Aceh Merdeka (AGAM) has been estimated at between 15,000 and 27,000 people, but they have only a few thousand modern firearms. ${ }^{114}$ It was reported that "some of GAM's membership was trained in Libya. In 1989, over one hundred Libyan-trained GAM guerillas returned to Aceh with rudimentary military training to try to give the then-moribund rebellion a new lease on life." 115

To curb this rebellion, President Suharto declared Aceh an area of military operation (Daerah Operasi Militer, DOM). Many Indonesian army personnel were sent to Aceh to fight GAM, both in villages and forests. Through 1989 and the first half of 1990, some 6,000 territorial

\footnotetext{
108 Tengku Hasan di Tiro, The Price of Freedom, p. 11. See also idem, "Konsep-Konsep Kunci Ideologi Acheh Merdeka”, Suara Acheh Merdeka, VII, 1995, pp. 29-37.

109 Tengku Hasan di Tiro, "Violations of Human Rights by Indonesia Acheh/Sumatra and Achehnese legitimate struggle for independence from Indonesia," $A G A M$ : Madjallah Angkatan Atjeb Meurdeka, No. 4, 1991, p. 19.

110 "Shock Therapy".

${ }^{111}$ Human Rights Watch, "Indonesia: The War in Aceh,” Vol. 13, No.4, 2001, p. 5.

112 See Kamaruzzaman Bustamam-Ahmad, Wajah Baru Islam di Indonesia (Yogyakarta: UII Press, 2004).

113 Human Rights Watch, "Indonesia”, p. 7.

114 ICG, Aceh: Can Autonomy Stem the Conflict”, 27 June, 2001, p. 11.

115 Human Rights Watch, "Indonesia”, p. 8.
} 
forces normally stationed in the region were mobilized to conduct counter-insurgency operations against the GPK. In July 1990, Suharto ordered the deployment of a further 6,000 troops, including two battalions of the Army's Special Forces Command (Komando Pasukan Khusus, Kopassus), and other elite counterinsurgency units. ${ }^{116}$ The number of Indonesian troops increased each year. In 1999, it was reported that police strength was estimated at 3,000. The armed forces number some 7,000-8,000 troops, including 1,000 marines. ${ }^{117}$ The outcome of this maneuver was that over a thousand Acehnese people were killed in the first three years of operations. It was reported that 871 were killed outright by the army, and 378 were missing and later turned up dead. More than 500 others are listed as "disappeared" and have never been found. ${ }^{118}$

The operations, however, ended in 8 August 1998, and General Wiranto, the commander of Indonesia's armed forces, said that the government apologized to the Acehnese people. Indonesia's sociopolitical situation had serious implications on the conflict of Aceh, because its government was very weak in 1998-1999. As result, since 1999 there have been many independence organizations in Aceh concerned with finding solutions to this problem.

One of the government's options to solve the conflict is to give Acehnese people the right to implement Islamic law. To do this, the government has offered several alternatives both in Banda Aceh (the capital city of Aceh) and Jakarta. According to some scholars, the implementation of Islamic law in Aceh will solve the problem there ${ }^{119}$ because of the fact that Islamic law has been implemented in Aceh since the first coming of Islam. ${ }^{120}$ This was perhaps the government's

\footnotetext{
116 "Shock Therapy".

${ }^{117}$ ICG Indonesian Briefing Paper, Aceh: Escalating Conflict, 2000, p. 4.

118 Al-Chaidar et.al., Aceh Bersimbah Darab: Mengungkap Penerapan Status Daerab Operasi Militer (DOM) di Aceh 1989-1998 (Jakarta: al-Kautsar, 1999), p. 106; Kamaruzzaman Bustamam-Ahmad, Islam Historis: Dinamika Studi Islam di Indonesia (Yogyakarta: Galang Press, 2002), pp. 296-297.

119 Interwiew with M. Hasbi Amiruddin, May, 2004; Interview with Al-Yasa Abu Bakar, June 2004; Interview with Yusuf Hasan, May 2004.

120 See Amirul Hadi, Islam and State in Sumatra: A Study of Seventeenth-Century Aceh (Leiden: Brill, 2004); H.M. Kaoy Syah and Lukman Hakiem, Keistimewaan Aceh dalam Lintasan Sejarab: Proses Pembentukan UU No.44/1999 (Jakarta: PB al-Jam'iyatul Washilyyah, 2000), pp. 11-59.
} 
reason for granting special autonomy through the Law No. 44 of 1999 allowing Aceh to implement shari precepts in its cultural and educational affairs. ${ }^{121}$

During former President Abdurrahman Wahid's administration, four days before he was impeached, the national parliament passed the Law No.18 of 2001 conferring special autonomy for the province of Aceh Special Region as the province of Nanggroe Aceh Darussalam.122 This law was due to be implemented on 1 January 2002 and it represented an important development in Jakarta's Aceh policy approach as it sought to convince the Acehnese to remain part of Indonesia by granting them considerable power of self-governance. The NAD law was formally ratified on 9 August 2001 by President Megawati, who described the legislation as her government's "main pillar for conflict resolution" in Aceh. ${ }^{123}$

The key provisions of the law, are the following: first, considerably increased revenue sharing of income from natural resources; second, the use of regional symbols and flags, although not as symbols of sovereignty; third, direct elections of the governor and vicegovernor-but not before August 2006-and of regents and vice regents; fourth, the appointments, but not dismissals, by the central authorities of the provincial police chief and the head of the provincial prosecutor's office, must by approved by the governor; and fifth, the establishment of a shari court. ${ }^{124}$ It was also stated that the main purpose of implementing shari was to uphold the basic tenet of Islam about justice by delivering social welfare (maqa al-sharian) to the Acehnese people. ${ }^{125}$

\section{The Dynamics of Implementing Islamic Law in Aceh}

Following the right of implementation of Islamic law in 2002, launched in Aceh, there are two groups that support this movement

\footnotetext{
121 ICG, “Aceh: Can Autonomy Stem the Conflict”, p. 10.

122 Michelle Ann Miller, "What's Special About Special Autonomy in Aceh", paper presented at Conference on the Historical Background of the Aceh Problem, Asia Research Institute, National University Singapore, 28-29 May, 2004, p. 11.

${ }^{123}$ Michelle Ann Miller, "What's Special About Special”, p. 11.

124 Staffan Bodemar, "Conflict in Aceh, Indonesia", p. 30. See also Michelle Ann Miller, "The Naggroe Aceh Darussalam Law: A Serious Response to Acehnese Separatism?”, Asian Ethnicity 15 (3), 2004, pp. 340-343.

125 Lily Zakiyah Munir, “Has Shari’a Brought Justice?”, The Jakarta Post, 2003.
} 
and two that oppose it. The supporters list many reasons why Aceh should implement Islamic law. The first is the fact that historically, Aceh has, in fact, already implemented Islamic law for many years. ${ }^{126}$ According to this opinion, any other legal systems are irrelevant because they were not based on the Acehnese tradition and history which are colored with Islamic teachings. It is claimed that the Indonesian legal system is not compatible with Acehnese traditions ${ }^{127}$ because it had not been used from the time of the coming of Islam until Aceh became a province of Indonesia. ${ }^{128}$

Second, the implementation of Islamic law is one way to resolve the conflict of Aceh. This view is argued by members of parliament in Jakarta when giving their overview on the issue of implementation of Islamic law in Aceh. The faction from the Indonesian army fully supports the bill of special autonomy for Aceh. But they propose that legal penalties in Aceh must be based on the Indonesian legal system. ${ }^{129}$ The PDI-P also supports this draft, because solving the conflict of Aceh requires not only a military approach but also a religious one. ${ }^{130}$ Moreover, the Acehnese elites, who were elected in June, 1999, were not critical of local members of parliament. ICG reported that this group is not particularly representative of Acehnese opinion in general, since many of its members are based in Jakarta rather in the province. ${ }^{131} \mathrm{It}$ is also said that the poor and less educated majority mistrusted the legislators, particularly the provincial parliament. ${ }^{132}$

The third reason cited by supporters of Islamic law is that this law represents the demand of Acehnese society. Thus, they argue, that ever since Aceh became part of Indonesia, the people felt that they were no longer Acehnese because they were following secular law in Indonesia.

\footnotetext{
${ }^{126}$ Interview with Al-Yasa, May, 2005; Interview with Yusuf Hasan, May 2004; and Marlinda, May, 2004.

127 Interview with Iskandar Budiman, May, 2004; Hasanuddin Yusuf Adan, May, 2004.

${ }^{128}$ See also, Al-Yasa Abubakar, Tanya Jawab Pelaksanaan Syariat Islam di Provinsi Nanggroe Aceh Darussalam (Banda Aceh: Dinas Syariat Islam, 2003), pp. 18-23.

129 Sudiyotomo, "ABRI Mendukung Penuh", in H.M. Kaoy Syah and Lukman Hakiem, Keistimewaan Aceh, p. 165.

130 Sajid Soetjoro, “Tidak Cukup Dengan Pendekatan Keamanan”, in H.M. Kaoy Syah and Lukman Hakiem, Keistimewaan Aceh, pp. 173-175.

131 ICG, “Aceh: Can Autonomy Stem the Conflict”, 2001, p. 14.

132 Ibid.
} 
Consequently, when the government granted the right to implement Islamic law, the Acehnese people felt that they became "more Acehnese." 133

Fourth, the implementation of Islamic law is supposed to eliminate moral decadency in Aceh, in the form of practices like corruption, collusion, and nepotism (KKN), or Korupsi (Corruption), Kolusi (Collusion), and Nepotisme (Nepotism). ${ }^{134}$ This view holds that KKN in Aceh is very widespread among local government officials. ${ }^{135}$ When I visited many offices in Banda Aceh and Lhokseumawe, I noticed that the civil servants look forward to large-scale projects. They routinely increase the budget, adding more rupiabs to each project. ${ }^{136}$ Some shari proponents felt that Islamic law would eliminate such practices in local government.

On the other hand, there are arguments against the implementation of Islamic law in Aceh. First, Islamic law in Aceh is claimed to be a step toward formalizing and symbolizing Islamic teaching. ${ }^{137}$ These views come from Islamic liberal thinkers in Jakarta, especially from the Liberal Islam Network (Jaringan Islam Liberal, JIL) and Nahdlatul Ulama (NU) youth. ${ }^{138}$ According to Azyumardi Azra, there is no state in the Muslim world that could be adopted as a model for the implementation of Islamic law. Consequently, he is very skeptical about the possibility of this movement succeeding in Aceh. Moreover, he refers to the implementation of Islamic law in Aceh as

133 Interview with Al-Yasa Abubakar, May 2004; Interview with Yusuf Hasan, May 2004; Nurjannah Ismail, May 2004; Marlinda Puteh, May 2004; Iskandar Budiman, May 2004.

134 Interview with Iskandar Budiman, May, 2004; Interview with Hasanuddin Yusuf Adan, May 2004; Interview with Mohd. Abdurrahman, June, 2004.

135 Interviews with M. Hasbi Amiruddin, May, 2004; Interview Helmy Hass, July, 2004; M. Adli Abdullah, July, 2004.

136 There are many names who suspected as Koruptor in Aceh, such as Abdullah Puteh (the Governor of Aceh),

137 See Marzuki Wahid and Nurrohman, "Dimensi Fundamentalisme dalam Politik Formalisasi Syariat Islam: Kasus Nanggroew Aceh Darussalam”, Tashwirul Afkar, No.13, 2002, pp. 34-59.

138 On this, see Kamaruzzaman Bustamam-Ahmad, "Metaformosis Pemikiran Intelektual Muda NU: Suatu Pandangan dari Outsider NU", Millah, Vol. IV, 2004, pp. 111-126; idem, Wajah Baru Islam di Indonesia, pp. 51-100; Zuly Qodir, "Wajah Islam Liberal di Indonesia: Sebuah Penjajagan Awal”, Al-Jarri'ah, Vol. 40, No. 2, 2002, pp. 325-353. 
merely a taken "gift" from the government for historical romanticism. ${ }^{139}$

Second, implementing Islamic law in Aceh will not solve the problem of conflict in Aceh. ${ }^{140}$ According to this view, the most important means of solving problems in Aceh is through the empowerment of civil society and socio-economic life. This view also argues that the implementation of Islamic law is only concerned with symbolic practices, ${ }^{141}$ such as the use of Arabic-Malay calligraphy on government offices and streets. In fact, Islamic law is not the answer to the war in Aceh. ${ }^{142}$

The third argument against Islamic law contends that its application in Aceh focuses only on women's issues. ${ }^{143}$ The most controversial issue of the implementation of Islamic law in Aceh is the position of women, including wearing jilbab (a long coat or cloak; more generally, any type of outer-garment that covers from the shoulders to the ankles). Nurjannah Ismail, a gender activist in Aceh, does not agree that the movement only concern on women. ${ }^{144}$ She maintains that "Islamic law is about handling women's matters" and "Islamic law does not mean that the men can do anything to women, including enforcing issues of aurat." This term refers to the part of a person's body that must be covered when in the presence of anyone but a spouse; for men this is from the navel to the knees, for women from the upper chest to the knees. ${ }^{145}$ However, Marlinda Puteh, wife of the Aceh ex-governor, argues that women hold a high position in Islamic

\footnotetext{
139 Azyumardi Azra, "Belum ada Negara Sebagai Acuan Pelaksanaan Syariat Islam," in Kurniawan Zein and Sarifuddin HA (eds.), Syariat Islam Yes, Syariat Islam No: Dilema Piagam Jakarta dalam Amademen UUD 1945 (Jakarta: Paramadina, 2001), p. 184; see also, idem, "Communal Riots in Indonesia: The Decline of Indonesia Nationalism and the Rise of Separatism", in Murni Jamal and Klaus Pahler (eds.), Communal Conflict in Contemporary Indonesia (Jakarta: The Center for Language and Culture and The Konrad Adeneur Foundation, 2002), pp. 82-87; idem, Konflik. Baru Antar Peradaban: Globalisasi, Radikalisme \& Pluralitas (Jakarta: Grafiti, 2002), pp. 126-132.

140 Interview with Irwandar, May 2004.

${ }^{141}$ Interview with Nurdin, July, 2004.

142 Suraiya Kamaruzzaman, "Women and Syariah in Aceh," Inside Indonesia, July-9 September, 2004.

${ }^{143}$ Interview with Ali Jauhary, May 2004; Interview with Nurjannah Ismail, May, 2004.

144 Interview with Nurjannah Ismail, May 2004.

145 Interview with Ali Jauhary, May 2004.
} 
as pillars of the state, and consequently, the first step in promoting Islamic law in Aceh is to have Acehnese women to wear jilbab in the public sphere to demonstrate that they are true Muslims. ${ }^{146}$

In reality, there were many sweepings carried out by Wilayatul Hisbah, an institute for shari Police in Aceh, involving women who wore tight clothing instead of jilbab. Al-Yasa Abubakar, who is the head of the shari division and a scholar at the State Institute of Islamic Studies (Institut Agama Islam Negeri, IAIN) in Banda Aceh, argues that this is not sweeping, but only popularizing the implementation of Islamic law in the city. ${ }^{147}$ Marlinda also supports this action, because sharith will succeed if women begin to present a good image of Aceh, and this starts with women's dress code. ${ }^{148}$ Commenting on this opinion, Suraiya Kamaruzzaman, a women activist and the founder of Flower Aceh in Banda Aceh, says that those interpreting Islamic law —ulama, the military, and civilian authoritieshave emphasized matters of individual worship. As a result, it appears that the implementation of sharity in Aceh has focused mainly on issues such as jilbab, the Friday prayer, and fasting during Ramadan. ${ }^{149}$

The methods of implementing Islamic in Aceh involved many steps and regulated many laws and qanuns, as follows: (1) Law No.44/1999 that gives Aceh the right to determine matters relating to religious and cultural affairs, education and the role of ulama, (2) Law No.18/2001, granting Aceh special autonomy as the province of Nanggroe Aceh Darussalam, (3) Regional Regulation No.5/2001, concerning the framework of the application of Islamic law, and (4) Regional Regulation No.33, discussing the Sharith division in Aceh.

The most basic step toward using Islamic law in daily life would be in education. Alyasa Abubakar says that the law will not be implemented if the Acehnese people don't become better educated. The first program to society is not to promote the law, but to educate the public about what the shari is if they understand the real shari it will not be necessary to regulate and promote the law because the implementation of Islamic law in Aceh is aimed at practicing Islamic

\footnotetext{
146 Interview with Marlinda Puteh, May 2004.

147 Interview with Al-Yasa Abubakar, May 2004.

148 Interview with Marlinda Puteh, May 2004.

${ }^{149}$ Suraiya Kamaruzzaman, Women and Syariah in Aceh, p. 11.
} 
teaching in a holistic manner (kafah). ${ }^{150}$ That is why, in Aceh, as Alyasa maintains, the purpose of Islamic law is not to discuss the brfduland so on, but rather, it is for the purpose of education. This idea is also supported by Yusuf Hassan, an Islamic leader in Banda Aceh, who says that the implementation of hifdu will take place in the next 60 years, that is, after society becomes better educated and understands the real shari 151

In implementing this law, however, the government encountered several conflicting situations. After the NAD law was passed, GAM demonstrated its rejection of autonomy by increasing its attacks on state facilities. The conflict also led many Acehnese government officials at the village and district levels to either abandon their offices or to reach some sort of arrangement with GAM members in GAMcontrolled areas. ${ }^{152}$ GAM's founding father, Hasan di Tiro, dismissed Jakarta's plans to introduce Islamic law as "irrelevant" because "the struggle of the Acehnese people never had anything to do with shari $"$ "153

\section{Conclusion}

As the historical overview portion of this study has demonstrated, Aceh has implemented Islamic law since the coming of Islam. Traditional Islamic education played an important role in disseminating Islamic law to the people. In Aceh, Islamic law was eliminated first by colonialists and later by the national government of Indonesia, respectively. I would like to argue that what the government means by Islamic law is hifdulaw. Thus, when the issue of Islamic law arose in Indonesia, it meant implementation of hidulaw, which is a fatal misinterpretation. In fact, Islamic law $(f i g h)$ is a human product of legal reasoning (ijtihat), as I elaborated above. The implementation of Islamic law in Aceh became a political issue for the elites. In Indonesia, the political elites made the issue of Islamic law in Aceh a strategy to

\footnotetext{
150 Interview with Al-Yasa Abubakar, May 2004.

${ }^{151}$ Interview with Yusuf Hasan, May 2004.

152 Michelle Ann Miller, "The Nanggroe Aceh Darussalam Law: A Serious Response to Acehnese", Asian Ethnicity, Vol. 15, No. 13, 2004, p. 342; Rodd McGibbon, "Secessionist Challenges in Aceh and Papua: Is Special Autonomy the Solution", Policy Studies, No. 10, 2004, p. 29.

153 Michelle Ann Miller, The Nanggroe Aceh Darussalam Law, p. 343.
} 
reach conflict resolution as well as to win national and local elections in Aceh. ${ }^{154}$

It is worth noting that the so-called "Islamic law" in Aceh is perceived by many as hidulaw. Nevertheless, this law has not yet been implemented in this province. However, some rules have been passed, based on Islamic teaching for the community, for example the checklist or razia by police in the street and public areas (such as cafés). The same holds true of Aceh, where the government has attempted to promote the Arabic script, especially for office logos. It is safe to say that the provincial government and its emphasis on symbolic religious issues (such as the Islamic dress code and usage of Arabic signs and letterheads), and its introduction of public lashings for petty offences like the sale and consumption of food during Ramadhan, are creating an image of shari based more on violence than on social justice. ${ }^{155}$

Moreover, in Aceh the issues surrounding the application of Islamic law are much more complex. On the one hand, the Islamic law movement began after independence, when Acehnese leaders declared Aceh to be an Islamic state. On the other hand, the issue of Islamic law became a means of solving problems in the Aceh conflict. Here, the government realized that the implementation of Islamic law in Aceh was an aspect of special autonomy. In Aceh, however, the issue of Islamic law is only a means of resolving conflict and gaining government support. But, in fact, there is a serious effort on the part of the Indonesian government to help the local government implement Islamic law. In Aceh, non-Muslims supported the need for implementation of Islamic law, saying that they understood that Acehnese society had implemented Islamic law for hundreds of years. ${ }^{156}$ But they urged that Islamic law apply only to Muslims. ${ }^{157}$

In summary, this study has provided the dynamic nature of the interpretation of Islamic law in Aceh. This province has not been able to apply Islamic law successfully because of many challenges, both external and internal, it has faced. At the same time, it has revealed Muslims' responses to the modern era, especially their rejection of

\footnotetext{
154 Ibid., pp. 348-351.

155 Michelle Ann Miller, “The Nanggroe Aceh Darussalam Law”, p. 345.

156 Hasan, "Syariat Islam yang Kami Pahami," in Fairus M. Nur Ibr (ed.), Syariat di Wilayah Syariat, p. 274

${ }^{157}$ Frietz R. Tambunan PR., "Pelaksanaan Syariat Islam”, pp. 288-89.
} 
secular law. Finally, the study has made evident that implementing Islamic law is never a good method of attempting to resolve conflict. There is no need to establish Islamic law formally through the political process because, when politics enters the religious arena, it carries with it many vested interests.

\section{Bibliography}

\section{Books and Articles}

Abdullah, Taufik. "Adat and Islam: An Examination of Conflict in Minangkabau", Indonesia, No. 2 (1966): pp. 1-24.

------. "Some Notes on the Kaba Tjindua Mato: An Example of Minangkabau Traditional Literature”, Indonesia, No.9 (1970): pp. $1-22$.

------. Islam Masyarakat: Pantulan Sejarah Indonesia. Jakarta: LP3ES, 1996.

--------. “Teungku Daud Beureueh: Pejuang Kemerdekaan yang Berontak.” Tempo, 24 August 2003.

Abubakar, Al-Yasa. Tamaddun \& Sejarah: Etnografi Kekerasan di Aceh. Yogyakarta: Prismasophie, 2003.

------. Tanya Jawab Pelaksanaan Syariat Islam di Provinsi Nanggroe Aceh Darussalam. Banda Aceh: Dinas Syariat Islam, 2003.

Ahmad, Shukri. "Implikasi Pengaruh Ulama Terhadap Halatuju Perubahan Pemikiran Politik Masyarakat Islam Wilayah Utara Semenanjung Malaysia Dari 1950-an Hingga 1990-an", Journal of Ushuluddin 14 (2001): pp. 97-122.

al-Chaidar, et al. Aceh Bersimbah Darah: Mengungkap Penerapan Status Daerah Operasi Militer (DOM) di Aceh 1989-1998. Jakarta: AlKautsar, 1999.

al-Faruqi, Maysam J. "Umma: The Orientalist and The Qur'anic Concept of Identity". Journal of Islamic Studies, Vol. 16, No. 1 (2005): pp. 1-34.

al-Mawardi, Abu Hasan. Al-Ahla al-Sulthimyah. Cairo: Mustafa alBabi al-Halabi, 1973. 


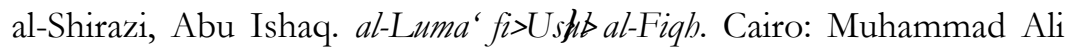
Sabih, 1900.

Ali, A. Mukti. An Introduction to the Government of Acheh's Sultanate. Yogyakarta: Jajasan Nida, 1970.

Amin, S.M. "Sejenak Meninjau Aceh, Serambi Mekkah", in Ismail Suny (ed.), Bunga Rampai tentang Aceh. Jakarta: Bhratara, 1980: pp. 45102.

Amiq. "Two Fatwas on Jihad against the Dutch Colonization in Indonesia: A Prosopographical Approach to the Study of Fatwä', Studia Islamika 5 (3) (1998): pp. 77-124.

Amiruddin, M. Hasbi. Ulama Dayah: Pengawal Agama Masyarakat Aceh, trans. by Kamaruzzaman. Lhokseumawe: Nadiya Foundation, 2003.

An-Na'im, Abdullah Ahmed. Toward an Islamic Reformation: Civil Liberties, Human Rights, and International Law. Syracuse: Syracuse University Press, 1990.

Anderson, J.N.D. Islamic Law in the Modern World. New York: New York University Press, 1959.

Anshari, Saifuddin. "Islam or the Pancasila as the Basis of the State", in Ahmad Ibrahim et al. (eds.), Readings on Islam in Southeast Asia. Singapore: ISEAS, 1985: pp. 221-228.

Ansari, Zafar Ishaq. "Foreword", in Imran Ahsan Khan Nyazee. Theories of Islamic Law: The Methodology of Ijtihala Pakistan: International Institute of Islamic Thought and Islamic Research Institute, 1994.

Anwar, Syamsul. "Islamic Jurisprudence of Christian-Muslim Relations: Toward a Reinterpretation", Al-Ja ariah, 61 (1997): pp. 128-153.

Auni, Luthfi. "The Declince of the Islamic Empire of Aceh". Master's thesis. McGill University, 1993.

Arfa, Faisar Ananda. Sejarah Pembentukan Hukum Islam: Studi Kritis tentang Hukum Islam di Barat. Jakarta: Pustaka Firdaus, 1996.

Atjeh, Aboebakar. "Tentang Name Aceh", in Ismail Suny (ed.). Bunga Rampai tentang Aceh. Jakarta: Bhratara, 1980: pp. 15-26. 
Attas, Muhammad Naquib Al-. A Commentary on the Hujjat al-Siddiq of Nur al-Din al-Raniri. Kuala Lumpur: Ministry of Culture, 1986.

Ayyub, Mahmoud. "Sulit, Menerapkan Sistem Politik Berbasis Syariah", Tashwirul Afkar, 13 (2002): pp. 121-125.

Azizy, A. Qodri. Eklektisisme Hukum Nasional: Kompetisi Antara Hukum Islam dan Hukum Umum. Yogyakarta: Gama Media, 2002.

-. "Juristic Differences (Ikbtilaf) in Islamic Law: its Meaning, Early Discussions, and Reasons (a Lesson for Contemporary Characteristics)", Al-Jami'ah 39(2) (2001).

Azra, Azyumardi. Menuju Masyarakat Madani: Gagasan, Fakta, dan Tantangan. Bandung: Rosdakarya, 1999.

--------. Pendidikan Islam: Tradisi dan Modernisasi Menuju Milenium Baru. Jakarta: Logos, 1999.

---------. Renaisans Islam Asia Tenggara: Sejarah Wacana \& Kekuasaan. Bandung: Rosdakarya, 1999.

-. "Tanbih al-Masyi; Otentisitas Kepakaran Abdurrauf Singkel”, in Oman Fathurrahman, Tanbih Al-Masyi. Bandung: Mizan, 1999.

"Belum ada Negara Sebagai Acuan Pelaksanaan Syariat Islam", in Kurniawan Zein and Sarifuddin HA (eds.). Syariat Islam Yes, Syariat Islam No: Dilema Piagam Jakarta dalam Amademen UUD 1945. Jakarta: Paramadina, 2001. -. "Communal Riots in Indonesia: The Decline of Indonesian Nationalism and the Rise of Separatism", in Murni Jamal and Klaus Pahler (eds.). Communal Conflict in Contemporary Indonesia. Jakarta: The Center for Language and Culture and the Konrad Adeneur Foundation, 2002.

--------. Konflik Baru Antar Peradaban: Globalisasi, Radikalisme \& Pluralitas. Jakarta: Grafiti, 2002.

Baderin, Mashood A. International Human Rights and Islamic Law. Oxford: Oxford University Press, 2003.

Barnard, Timothy P. (ed.). Contesting Malayness: Malay Identity Across Boundaries. Singapore: National University of Singapore, 2004. 
Bowen, John R. "You May Not Give it Away': How Social Norms Shape Islamic Law in Contemporary Indonesian Jurisprudence", Islamic Law and Society 5 (3) (1998): pp. 382-408.

Bustamam-Ahmad, Kamaruzzaman. "Kontribusi Daerah Aceh terhadap Perkembangan Awal Hukum Islam di Indonesia". AlJâmiah, 64 (1999): pp. 143-175.

--------. "Hukum Islam dalam Konteks Masyarakat Madani”. Mimbar Hukum, 48 (2000): 23-33.

--------. “Perdebatan Mengenai Negara Islam". Siasah, November 2001: pp. 26-27.

------. "Relasi Agama [Islam] dan Politik". Siasah, October 2001: 2629.

--------. "Hubungan Agama dan Negara”. Pemikir, 30 (2002): 93-119.

--------. Islam Historis: Dinamika Studi Islam di Indonesia. Yogyakarta: Galang Press, 2002.

--. “Konsep Negara Era Moden”. Pemikir, 31 (2003): pp. 233258.

--------. "Menakar Harga Kemarahan Orang Aceh: Ethnografi Kekerasan di Indonesia", in Hasanuddin Yusuf Adan, Tamaddun dan Sejarah: Etnografi Kekerasan di Aceh. Yogyakarta: Ar-Ruzz, 2003: pp. 9-38.

-------. Satu Dasawarwa the Clash of Civilizations. Yogyakarta: Ar-Ruzz, 2003.

-. "Metamorfosis Pemikiran Intelektual Muda NU: Suatu Pandangan dari Outsider NU”, Millah, 4 (2) (2004): 111-126.

------. Wajah Baru Islam di Indonesia. Yogyakarta: UII Press, 2004.

Case, William. Politics in Southeast Asia. Richmond, UK: Curzon Press, 2002.

Choudhury, G.W. Islam and the Modern Muslim World. Kuala Lumpur: WHS Publications, 1993.

Constable, Olivia Remie, "Reconsidering the Origin of the Funduq", Studia Islamica, No. 92 (2001): pp. 195-196.

Dahlan, Abdul Azis, et al. (eds.). Ensiklopedi Hukum Islam. Jakarta: Ichtiar van Hoeve, 1997. 
Daly, Peunoh. Hukum Perkawinan Islam: Suatu Studi Perbandingan dalam Kalangan Ablus-Sunnah dan Negara-negara Islam. Jakarta: Bulan Bintang, 1988.

Dawam, Rahardjo M. "The Kyai, the Pesantren, and the Village: A Preliminary Sketch", in Ahmad Ibrahim et. al. (eds.). Readings on Islam in Southeast Asia. Singapore: ISEAS, 1985.

Dengel, Holk H. Darul Islam dan Kartosuwirjo. Jakarta: Sinar Harapan, 1995.

Dja'far, Muhammad Alfian. "Independensi Mahkamah Syariah Nanggroew Aceh Darussalam”. Bachelor's thesis, State Institute of Islamic Studies, Yogyakarta, 2003.

Dhofier, Zamahksyari. Tradisi Pesantren: Studi tentang Pandangan Hidup Kyai. Jakarta: LPES, 1996.

di Tiro, Tengku Hasan. The Price of Freedom: the Unfinished Diary of TengkuHasan di Tiro. N.p.: National Liberation of Acheh Sumatra, 1984.

-. Violations of Human Rights by Indonesia Acheh/Sumatra and Achehnese Legitimate Struggle for Independence from Indonesia," AGAM: Madjallah Angkatan Atjeb Meurdeka 4 (1991).

-------. "Konsep-Konsep Kunci Ideologi Acheh Merdeka," Suara Acheh Merdeka, VII (1995).

-. "Nasionalisme Indonesia", in Yusra Habib Abdul Ghani, Mengapa Sumatera Menggugat, n.p.: Biro Penerangan AchehSumatra National Liberation Front, 2000.

Dobbin, Christine. "Islamic Revivalism in Minangkabau at the Turn of the Nineteenth Century", Modern Asian Studies, Vol. 8, No. 3 (1974): pp. 319-345.

Drewes, G.W.J. "New Light on the Coming of Islam to Indonesia." in Ahmad Ibrahim et. al. (eds.). Readings on Islam in Southeast Asia. Singapore: Institute of Southeast Asian Studies (1985): pp. 7-19.

Fathurahman, Oman. Tanbih al-Masyi, Menyoal Wahdatul Wujud: Kasus Abdurrauf Singkel di Aceh Abad 17. Bandung: Ecole Francaise D'extreme-orient and Mizan, 1999. 
Fatimi, S.Q. Islam Comes to Malaysia. Singapore: Malaysia Sociological Research Institute LTD, 1963.

Fernando, Joseph M. "The Position of Islam in the Constitution of Malaysia", Journal of Southeast Asian Studies, Vol. 37, No. 2 (2006): pp. 249-266

Gleave, Robert. Inevitable Doubt: Two Theories of Shi i Jurisprudence. Leiden: Brill, 2000.

--------. and E. Kermeli (eds.). Islamic Law: Theory and Practice. New York: I.B. Tauris, 1997.

Guinn, David E. et. al. (eds.). Religion and Law in the Global Village. Atlanta: Scholars Press, 1999.

Hallaq, Wael B. "Was the Gate of Ijtihad Closed?", International Journal of Middle East Studies 16 (1984): 3-41.

-. "On the Origins of the Controversy about the Existence of Mujtahids and the Gate of Ijtihad", Studia Islamica, 63 (1986): pp. 129-141.

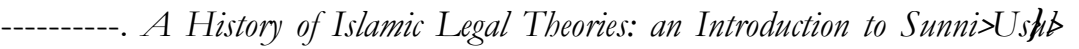
Fiqh. Cambridge: Cambridge University Press, 1997.

Hasan. "Syariat Islam yang Kami Pahami", in Fairus M. Nur Ibr (ed.). Syariat di Wilayah Syariat: Pernik-Pernik Islam di Nanggroe Aceh Darussalam. Banda Aceh: Dinas Syariat Islam, 2002.

Hassan. Abdullah Alwi Haji. The Administration of Islamic Law in Kelantan. Kuala Lumpur: Dewan Bahasa dan Pustaka, 1996.

Hassan, Ahmad. Pintu Ijtihad Sebelum Tertutup, trans. by. Agah Garnadi. Bandung: Pustaka, 1994.

Hadi, Amirul. Islam and State in Sumatra: A Study of Seventeenth-Century Aceh. Leiden: Brill, 2004.

--------. "Aceh and the Portuguese: A Study of the Struggle of Islam in Southeast Asia". Master's thesis. McGill University, 1992.

Hamzah, Tengku Razaleigh. "The Semangat 46 View”, in Rose Ismail (ed.). Hudud in Malaysia. Selangor: Ilmiah Publishers, 2002.

Hefner, Robert W. Civil Islam: Muslim and Democratization in Indonesia. Princeton, NJ: Princeton University Press, 2000. 
Hing, Lee Kam. The Sultanate of Aceb: Relations with the British 1760-1824. Kuala Lumpur: Oxford University of Press, 1995.

Holleman, J.F. (ed.). Van Vollenhoven on Indonesia Adat Law. The Hague: Koninklijk Instituut Voor Taal-Land en Volkenkunde, 1981.

Hooker, M.B. Islamic Law in Southeast Asia. Singapore: Oxford University Press, 1984.

-. (ed.). Islam in South-East Asia. Leiden: E.J. Brill, 1983.

-. Islamic Law in South East Asia. Singapore: Oxford University Press, 1984.

-. "State and Syari'ah in Indonesia 1945-1995", in Timothy Lindsey (ed.). Indonesia: Law and Society. Sydney: Federation Press, 1999.

-. "Introduction: Islamic Law in Southeast Asia", Asian Law 2 (2002): pp. 213-231.

------. Islam Maz̧ab Indonesia: Fatwa-Fatwa dan Perubahan Sosial. Bandung: Mizan, 2003.

Hourani, George F. "Joseph Schacht 1902-69”, Journal of the American Oriental Society, Vol. 90, No. 2 (1970): pp. 167-167.

-. "Islamic and Non-Islamic Origins of Mu'tazilite Ethical Rationalism", International Journal of Middle East Studies, Vol. 7, No. 1 (1976): 59-87.

Human Rights Watch. "Indonesia: The War in Aceh", 13 (4) (2001).

Hurgronje, C. S. The Acehnese. Leiden: E.J. Brill, 1906.

Ibrahim, Rosli. "Isu Malaysia Negara Islam: Antara Kenyataan dan Kejahilan”, Siasab 7 (2001): pp. 29-30.

ICG. “Aceh: Escalating Conflict”. 7 December 2000.

-------. “Aceh: Can Autonomy Stem the Conflict?”. June 27, 2001.

Muhamed Yusof Ismail. "Buddhism in a Muslim State: Theravada Practices and Religious Life in Kelantan". Workshop Proceedings "A Plural Peninsula: Historical Interactions among the Thai, Malays, Chinese and Others". Walailak University, 5-7 February 2004.

Ismuha. "Adat and Agama di Aceh". Working Paper No. 16. Darussalam: Pusat Latihan Penelitian Ilmu-ilmu Sosial, 1983. 
-. "Ulama Aceh Dalam Perspektif Sejarah", in Taufik Abdullah (ed.). Agama dan Perubahan Sosial. Jakarta: Raja Grafindo Persada, 1996.

Johansen, Baber. Contingency in a Sacred Law: Legal and Ethical Norms in the Muslim Fiqh. Leiden: Brill, 1999.

Ka'bah, Rifyal. "Pluralisme dalam Perspektif Syariah", Mimbar Hukum 5 (2001): pp. 7-14.

Kamali, Mohammad Hashim. Punishment in Islamic Law: An Enquiry into the Hudud Bill of Kelantan. Kuala Lumpur: Ilmiah Publishers, 2000.

Kamaruzzaman, Suraiya. "Women and Syariah in Aceh", Inside Indonesia, July-September 2004.

Kaoy Syah and Lukman Hakiem (eds.). Keistimewaan Aceh dalam Lintasan Sejarah: Proses Pembentukan UU No.44/1999. Jakarta: Pengurus Besar Al-Jami'iyatul Washliyyah, n.d.

Kaptein, Nico. The Mubimmatal-Nafa a Bilingual Meccan Fatwa Collection for Indonesian Muslims from the End of the Nineteenth Century. Jakarta: INIS, 1997.

--------. "Acceptance, Approval and Aggression: Some Fatwas Concerning the Colonial Administration in the Dutch East Indies", Al-Jarriah, 38 (2) (2000): pp. 297-330.

Kasimin, Amran. Religion and Social Change among the Indigenous People of the Malay Peninsula. Kuala Lumpur: Dewan Bahasa dan Pustaka Kementerian Pendidikan Malaysia, 1991.

Khallaf, Abdul Wahhab. IIm Ushul al-Figh. Beirut: Dar al-Qalam, 1978.

Kim, Khoo Kay. "Introduction", in Hugh Clifford, An Expedition to Trengganu \& Kelantan 1895. Kuala Lumpur: MBRAS, 1992.

-. Malay Society Transformation \& Democratisation: a Stimulating and Discerning Study of the Evolution of Malay Society. Selangor: Pelanduk Publications, 2001.

Layish, Aharon. 'Notes on Joseph Schacht's Contribution to the Study of Islamic Law", Bulletion (British Society for Middle Eastern Studies), Vol. 9, No. 2 (1982): pp. 132-140.

Lev, Daniel S. Islamic Courts in Indonesia: a Study in the Political Bases of Legal Institutions, Berkeley: University of California Press, 1972. 
Liow, Joseph. "Deconstructing Political Islam in Malaysia: UMNO's Responses to PAS' Religio-Political Dialectic", Working Paper, No. 45. Singapore: Institute of Defence and Strategic Studies, 2003.

Lombard, Denys. Kerajaan Aceh: Jaman Sultan Iskandar Muda (16071636), trans. by Winarsih Arifin. Jakarta: Balai Pustaka, 1986.

Lukito, Ratno. "Law and Politics in Post Independence Indonesia: a Case Study of Religious and Adat Courts." Studia Islamika 6(2) (1999): pp. 63-86.

-------. Islamic Law and Adat Encounter: The Experience of Indonesia. Jakarta: Logos, 2001.

Mahmood, Tahir (ed.). Human Rights in Islamic Law. New Delhi: Genuine Publications, 1993.

Masud, Mohd. Khalid, et. al. (eds.). Islamic Legal Interpretation. Cambridge, MA: Harvard University Press, 1996.

Mas'udi, Masdar F. "Hak Azasi Manusia dalam Islam", in E. Shobirin Nadj and Naning Mardiniah (eds.). Diseminasi Hak Asasi Manusia: Perspektif dan Aksi. Jakarta: LP3ES, 2000: pp. 63-72.

Masud, Abdurrahman. "Why the Pesantren in Indonesia Remains Unique and Stronger", in Isma-ae Alee et al. (eds.). Islamic Studies in ASEAN: Presentations of an International Seminar. Pattani: Prince of Songkhla University, 2000.

Mayer, Ann Elizabeth (ed.). Property, Social Structure and Law in the Modern Middle East. Buffalo: State University of New York Press, 1985.

-. Islam and Human Rights: Tradition and Politics. Boulder, Col.: Westview Press, 1991.

. "A Critique of An-Naim's Assesment of Islamic Criminal Justice", in T. Lindholm and K. Vogt (eds.). Islamic Law Reform and Human Rights: Challenges and Rejoinders. Oslo: Norwegian Institute of Human Rights, 1993.

-. "Religious Legitimacy and Consitutionalism: The Saudi Basic Law and the Moroccan Consitution Compared", in David E. Guinn et. al. (eds.). Religion and Law in the Global Village. Atlanta: Scholars Press, 1999: pp. 81-97. 
McGibbon, Rodd. "Secessionist Challenges in Aceh and Papua: Is Special Autonomy the Solution?”, Policy Studies, 10 (2004).

Mehden, Fred R. Von Der. "Malaysia: Islam and Multiethnic Polities", in John L. Esposito (ed.). Islam in Asia: Religion, Politics, and Society. New York: Oxford University Press, 1987.

Miller, Michelle Ann. "The Nanggroe Aceh Darussalam Law: a Serious Response to Acehnese," Asian Ethnicity 15 (13) (2004).

---------. "What's Special About Special Autonomy in Aceh", paper presented at Conference on the Historical Background of the Aceh Problem, Asia Research Institute, National University Singapore, May 28-29, 2004.

Minhaji, Akh. "Problem Gender dalam Perspektif Sejarah Hukum Islam". Nabila 1 (1998): pp. 14-26.

" "Ahmad Hassan and Islamic Legal Reform in Indonesia (1887-1959)”. PhD. Dissertation, McGill University, 1997.

--------. "Editorial: a Problem of Methodological Approaches to Islamic Law Studies", Al-Jarri'ah, 63 (1999).

--------. "Reorientasi Kajian Ushul Fiqh". Al-Jamäah, 62 (1990): pp. 23-24.

-. "Supremasi Hukum dalam Masyarakat Madani: Perspektif Sejarah Hukum Islam”. UNISIA, 41 (2000).

--------.. Abmad Hassan and Islamic Legal Reform in Indonesia (1887-1959). Yogyakarta: Kurnia Kalam Semesta Press, 2001.

-------. Kontroversi Pembentukan Hukum Islam: Kontribusi Joseph Schacht. Yogyakarta: UII Press, 2001.

.. "Modern Trends in Islamic Law: Notes on J.N.D. Anderson's Life and Thought", Al-Jariah, 39 (1) (2001).

-. "Noel James Coulson dalam Perspektif Orientalisme Hukum Islam", in Noel J. Coulson, Konflik dalam Yurisprudensi Islam, trans. by Fuad Zein. Yogyakarta: Navilla, 2001.

-. "Zakat dalam Konteks Otonomi Daerah", in Tafsir Baru Studi Islam dalam Era Multi Kultural. Yogyakarta: IAIN Sunan Kalijaga - Kurnia Kalam Semesta, 2002: pp. 211-236.

Mohamad, Saifulizam. "Antara Hudud Allah dan 'Hudud PAS". Massa, 13-19 July, 2002: pp. 16-17. 
Mortel, Richard T. "Madrasas in Mecca during the Medieval Period: A Descriptive Study Based on Literary Sources", Bulletin of the School of Oriental and African Studies, Vol. 60, No. 2 (1997): pp. 236-252.

Mudzhar, Muhammad Atho. Fatwa-Fatwa Majelis Ulama Indonesia. Jakarta: INIS, 1993.

-. "Fiqh dan Reaktualisasi Ajaran Islam." in Budhy Munawar Rahman (ed.). Kontekstualisasi Doktrin Islam dalam Sejarah. Jakarta: Paramadina, 1995: pp. 372-375.

-------. “The Council of Indonesian 'Ulama' on Muslims' Attendance at Christmas Celebrations", in Muhammad Khalid Masud, et. al. (eds.). Islamic Legal Interpretations. Cambridge, MA: Harvard University Press, 1996: pp. 230-241.

--------. Membaca Gelombang Ijtihad: Antara Tradisi dan Liberasi. Yogyakarta: Titian Ilahi Press, 1998.

-. "Social History Approach to Islamic Law", Al-Jarzi' ah, 61 (1998): pp. 78-88.

------. "Dirasat al-Ahkam al-Islamiyyah bin Mandhur 'Ilm alIjtima", Al-Jarriah, 65 (2000).

-. "Studi Hukum Islam dengan Pendekatan Sosiologi", in M. Amin Abdullah et. al. (eds.). Antologi Studi Islam: Teori \& Practice. Yogyakarta: IAIN Sunan Kalijaga, 2000: pp. 239-271.

-------. "The 'Ulama' $>$ the Government, and Society in Modern Indonesia: The Indonesian Council of "Ulama $>$ Revisited", in Johan Meuleuman (ed.). Islam in the Era of Globalization: Muslim Attitudes towards Modernity and Identity. Jakarta: INIS, 2001: pp. 315-326.

Muhammad, Mahathir. "Islam Guarantees Justice for All Citizens", in Rose Ismail (ed.). Hudud in Malaysia. Selangor: Ilmiah Publishers, 2002.

Muhammad, Tengku Ahmad. "Dikir Barat Kelantan dan Kriteria: Perlukah Reformasi di Dunia Hiburan?”, Seumbi (2001): pp. 3435.

Nasution, Khoiruddin. Status Wanita di Asia Tenggara: Studi Terhadap Perundang-undangan Perkawinan Muslim Kontemporer di Indonesia dan Malaysia. Jakarta: INIS, 2002. 
Nurhaidi. "Muslims' Participation in Christmas Celebrations: a Critical Study on the Fatwa of the Council of Indonesian Ulama", AlJarria 40 (2) (2002): pp. 280-301.

Osman Mohd. Taib. "Islamization of the Malays: a Transformation of Culture", in Ahmad Ibrahim et. al. (eds.). Readings on Islam in Southeast Asia. Singapore: ISEAS, 1985.

Othman, Mohammad Redzuan. "Masjid Al-Haram dan Peranannya dalam Perkembangan Awal Pendidikan dan Intelektualisme Masyarakat Melayu", Jurnal Usuluddin 13 (2001).

-----. "The Middle East Influence on the Development of Religious and Political Thought in Malay Society 1880-1940". Ph.D Dissertation, University of Edinburgh, 1994.

Othman, Mahmud Saedon Awang. "Islamic Law and Its Codification", IIU Law Journal, 1 (1) (1989): pp. 51-82.

Powers, David S. Studies in Al-Qur'an and Hadith: the Formation of the Islamic Law of Inheritance. Berkeley: University of California Press, 1986.

Qodir, Zuly. "Wajah Islam Liberal di Indonesia: Sebuah Penjajagan Awal”, Al-jaritah, 40 (2) (2002): pp. 325-353.

Rauf, Muhammad Abdul. "Al-Hadith: Its Authority and Authencity", IIU Law Journal 1 (1) (1989).

Reid, Anthony. "Introduction", in Anthony Reid (ed.), The Making of an Islamic Political Discourse in Southeast Asia. Victoria: Center of Southeast Asian Studies, 1993: pp. 1-16.

-. "Perlawanan dalam Sejarah Nanggroe Aceh Darussalam", Tempo, 24 August 2003.

Roberts, Robert. The Social Laws of the Quran. London: Curzon Press, 1924.

Sabiq, Sayyid. Figh al-Sunnah. Beirut: Dar al-Fikr, 1992.

Saby, Yusny. Islam and Social Change: The Role of the Ulama in Acehnese Society. Ph.D Dissertation, Temple University, 1995.

---------. "The Ulama in Aceh: A Brief Historical Survey", Studia Islamika 8 (1) (2001): pp. 1-54.

SAIS. "Political Islam in Southeast Asia" Conference Report, March 25, 2003, Johns Hopkins University, www.sais-jhu.edu/pro- 
grams/asia/asiaoverview/Publications/Southeast $\% 20$ Asia/Political\%20Islam\%20Report.pdf [accessed on October 2004].

Schacht, Joseph. An Introduction to Islamic Law. Oxford: Clarendon Press, 1964.

-------. The Origins of Mubammadan Jurisprudence. Oxford: Clarendon Press, 1975.

Seng, Ann Wan. "Kenapa DAP Keluar Barisan Alternatif?", Siasah November 2001.

Siraj, Mehruj. "Women and the Law: Significant Development in Malaysia", Law \& Society Review, 28 (23) (1994): pp. 561-572.

Stark, Jan. "The Islamic Debate in Malaysia: the Unfinished Project", South East Asia Research, 11 (2) (2003).

.- "Constructing an Islamic Model in Two Malaysian States: PAS Rule in Kelantan and Trengganu", SOJOURN, 19 (1) (2004).

Strawson, John. "Encountering Islamic Law", Mimbar Studi, 3 (1999): pp. 205-240.

Steenbrink, Karel A. Beberapa Aspek Tentang Islam di Indonesia Abad ke19. Jakarta: Bulan Bintang, 1984.

Sujitno, Sutedjo and Mashud Achmad. Aceb: Past, Present, \& Future. Banda Aceh: Kantor Gubernur, 1995.

Suryadinata, Leo, et. al. Penduduk Indonesia: Etnis dan Agama dalam Era Perubahan Politik. Jakarta: LP3ES, 2004.

Syah, Kaoy and Lukman Hakiem (eds.). Keistimewaan Aceh dalam Lintasan Sejarab: Proses Pembentukan UU No.44/1999. Jakarta: Pengurus Besar Al-Jami'iyatul Washliyyah, n.d.

Syurbashi, Ahmad. Al-A'immah al-Arba'ah. Beirut: Dar al-jil, n.d.

Tambunan, Frietz R. "Pelaksanaan Syariat Islam: Sebuah Refleksi Berdasarkan Pengalaman Gereja (Katolik)", in Fairus M. Nur Ibrahim (ed.). Syariat di Wilayah Syariat: Pernik-Pernik Islam di Nanggroes Aceh Darussalam. Banda Aceh: Dinas Syariat Islam, 2002.

Tibi, Bassam. Islam and the Cultural Accomodation of Social Change, trans. by Clare Krojzl. Boulder, CO: Westview Press, 1991. 
Tim Penulis Paramadina. Fiqh Lintas Agama: Membangun Masyarakat Inklusif-Pluralis. Jakarta: Paramadina and the Asia Foundation, 2003.

van Bruinessen, Martin. Kitab Kuning Pesantren dan Tarekat: TradisiTradisi Islam di Indonesia. Bandung: Mizan, 1999.

van Dijk, C. "Is God a Gangster? Political and Religious Authority and Religious Sentiments", paper presented at an IIAS and ISIM Workshop on "Fatwas and the Dissemination of Religious Authority in Indonesia", 31 October 2002.

Wahid, Marzuki and Nurrohman. "Dimensi Fundamentalisme dalam Politik Formalisasi Syariat Islam: Kasus Nanggroe Aceh Darussalam", Tashwirul Afkar, 13: pp. 34-57.

Weiss, Bernard G. (ed.). Studies in Islamic Legal Theory, Leiden: Brill, 2002.

Woodward, Mark R. Toward a New Paradigm: Recent Developments in Indonesian Islamic Thought. Tempe: Arizona State University, 1996.

Yasin, Norhamshimad Moh. Islamisation/Malaynisation: a Study on the Role of Islamic Law in the Economic Development of Malaysia, 19691993. Kuala Lumpur: Pustaka Hayati, 1996.

Yasuda, Nobuyuki. "Law and Development in ASEAN Countries", ASEAN Economic Bulletin, 10 (2) (1993): pp. 144-154.

Zain, Mohn Izani bin Mohd. "Barisan Alternatif Selepas Tiga Tahun", Minda, June 2002.

\section{Electronic Sources}

Amnesty International. "Shock Therapy': Restoring Order in Aceh, 19891993”, Mon. Aug 02, http://acehnet.tripod.com/shock.htmfx

"Mahathir: Malaysia is a 'fundamentalist state"' http://archives.cnn.com/2002/WORLD/asiapcf/southeast/06/18/malaysia.mahat hir, accessed 15 October 2004.

http://www.parti-pas.org/IslamicStateDocument.php.

\section{Interviews}

Ali Jauhary, May 2004.

Al-Yasa Abubakar, May 2004.

Hasanuddin Yusuf Adan, May 2004. 
Kamaruzzaman Bustaman-Ahmad

Helmy Hass, July 2004

Irwandar, May 2004.

Iskandar Budiman, May 2004.

M. Hasbi Amiruddin, May 2004.

M. Adli Abdullah, July 2004.

Mohd. Abdurrahman, June 2004.

Marlinda Puteh, May 2004.

Mudawali, May 2004

Nurdin, July 2004.

Nurjannah Ismail, May 2004.

Safwan Idris, July1999.

Yusuf Hasan, May 2004. 